OPEN ACCESS

Edited by:

Hailing Xin,

Second Military Medical

University, China

Reviewed by:

Xiaolu Lu,

Gannan Medical University, China

Jiumao Lin,

Fujian University of Traditional Chinese

Medicine, China

*Correspondence:

Chuan Zheng

zhengchuan@cdutcm.edu.cn

Jiasi Wu

jswoodr@hotmail.com

${ }^{+}$These authors have contributed equally to this work

Specialty section: This article was submitted to

Ethnopharmacology,

a section of the journal

Frontiers in Pharmacology

Received: 11 January 2020

Accepted: 20 March 2020

Published: 28 April 2020

Citation:

Tian R, Liu X, Luo Y, Jiang S, Liu H, You F, Zheng $C$ and Wu J (2020) Apoptosis Exerts a Vital Role in the

Treatment of Colitis-Associated Cancer by Herbal Medicine.

Front. Pharmacol. 11:438. doi: 10.3389/fphar.2020.00438

\section{Apoptosis Exerts a Vital Role in the Treatment of Colitis-Associated Cancer by Herbal Medicine}

\author{
Ruimin Tian ${ }^{1,2+}$, Xianfeng Liu ${ }^{1 \dagger}$, Yanqin Luo ${ }^{1}$, Shengnan Jiang ${ }^{1}$, Hong Liu ${ }^{3}$, \\ Fengming You ${ }^{3}$, Chuan Zheng ${ }^{3 *}$ and Jiasi $\mathrm{Wu}^{4 *}$ \\ ${ }^{1}$ College of Pharmacy, Chengdu University of Traditional Chinese Medicine, Chengdu, China, ${ }^{2}$ Department of \\ Pharmacology, North Sichuan Medical College, Nanchong, China, ${ }^{3}$ Hospital of Chengdu University of Traditional Chinese \\ Medicine, Chengdu, China, ${ }^{4}$ Innovative Institute of Chinese Medicine and Pharmacy, Chengdu University of Traditional \\ Chinese Medicine, Chengdu, China
}

Colitis-associated cancer (CAC) is known as inflammatory bowel disease (IBD)-developed colorectal cancer, the pathogenesis of which involves the occurrence of apoptosis. Western drugs clinically applied to CAC are often single-targeted and exert many adverse reactions after long-term administration, so it is urgent to develop new drugs for the treatment of CAC. Herbal medicines commonly have multiple components with multiple targets, and most of them are low-toxicity. Some herbal medicines have been reported to ameliorate CAC through inducing apoptosis, but there is still a lack of systematic review. In this work, we reviewed articles published in Sci Finder, Web of Science, PubMed, Google Scholar, CNKI, and other databases in recent years by setting the keywords as apoptosis in combination with colitis-associated cancer. We summarized the herbal medicine extracts or their compounds that can prevent CAC by modulating apoptosis and analyzed the mechanism of action. The results show the following. (1) Herbal medicines regulate both the mitochondrial apoptosis pathway and death receptor apoptosis pathway. (2) Herbal medicines modulate the above two apoptotic pathways by affecting signal transductions of IL-6/STAT3, MAPK/NF- $\kappa$ B, Oxidative stress, Noncanonical TGF- $\beta 1$, WNT/ $\beta$-catenin, and Cell cycle, thereby ameliorating CAC. We conclude that following. (1) Studies on the role of herbal medicine in regulating apoptosis through the Ras/Raf/ERK, WNT//-catenin, and Cell cycle pathways have not yet been carried out in sufficient depth. (2) The active constituents of reported anti-CAC herbal medicine mainly include polyphenols, terpenoids, and saccharide. Also, we identified other herbal medicines with the constituents mentioned above as their main components, aiming to provide a reference for the clinical use of herbal medicine in the treatment of CAC. (3) New dosage forms can be utilized to elevate the targeting and reduce the toxicity of herbal medicine.

Keywords: apoptosis, herbal medicine, colitis-associated cancer, signaling pathways, inflammatory bowel disease 


\section{INTRODUCTION}

Colorectal cancer (CRC) is the third most common cause of malignancy incidence and death. In the United States alone, there were more than 140,000 newly diagnosed CRC patients and more than 50,000 deaths last year (2018) (Keum and Giovannucci, 2019). A recent epidemiological study announced that the early onset of CRC dominantly occurred among the white races and females (Glover et al., 2019). Though the overall CRC rates have been reducing over recent years, evidence shows that there is a trend of increasing incidence among young people. Family medical history only accounts for about $20 \%$ of CRC cases, while environmental factors, obesity, smoking, alcohol abuse, and inflammatory bowel disease (IBD), in particular, are the main contributors (Serebriiskii et al., 2019). Crohn's disease (CD) and ulcerative colitis (UC) are the two defined IBD subtypes, and IBD-preceded CRC is known as colitisassociated cancer (CAC). Current data show that UC increases the cumulative risk of CAC by 18 to 20 percent, while CD increases the cumulative risk by 8 percent after 30 years. The exact overall increase in CAC prevalence in IBD patients depends on the severity and duration of the disease, the patient population analyzed, the availability of prophylactic colonoscopy in the general population, and the effectiveness of antiinflammatory therapy (Al Bakir et al., 2018; Zhu et al., 2019). The chronic inflammation-cancer relationship was first mentioned about one and a half centuries ago and had been confirmed by numerous clinical trials. Recent studies indicate that the most apparent correlation between long-term inflammation and tumor progression is observed in CAC, owing to the genetic change and epigenetic alteration elicited by inflammation (Romano et al., 2016; Hnatyszyn et al., 2019).

\footnotetext{
Abbreviations: AG, American ginseng; AOM, azoxymethane; APC, adenomatous polyposis coli; ASA, aminosalicylates; Bcl-2, B-cell lymphoma-2; Bcl-Xl, B-cell lymphoma-Extra Large; CAC, Colitis-associated cancer; $\mathrm{CD}$, Crohn's disease; CDC25A, cell division cycle 25A; CDK2, cyclin-dependent kinase 2; CDK4, cyclin-dependent kinase 4; CDK6, cyclin-dependent kinase 6; CDKI, cyclindependent kinase inhibitor; c-FLIP, cellular FLICE like inhibitory protein; COX-2, Cyclooxygenase-2; CRC, Colorectal cancer; DISC, death-inducing signaling complex; DSS, dextran sodium sulfate; EAPP, extract from the aerial parts of Artemisia princeps Pampanini cv.; FADD, Fas-associated death domain; Fas, factor associated suicide; Fas-L, Fas ligand; GLT, Trierpene extract isolated from Mushroom Ganoderma lucidum; GDNPs, ginger-derived nanoparticles; HQD, Huangqin Decoction; IAP, inhibitor of apoptosis proteins; IBD, inflammatory bowel disease;IL-1 $\alpha$, interleukin- $1 \alpha$; IL-1 $\beta$, interleukin-1 $\beta$; IL-6, interleukin-6; IL-17, interleukin-17; iNOS, inducible nitric oxide synthase; JAK: janus kinase; MAPK, mitogen-activation protein kinase; MCMP, mitochondrial

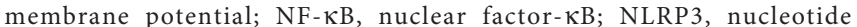
oligomerization domain (NOD)-like receptor protein-3; NOD/TLR, nucleotide binding oligomerization domain/toll like receptors; PCNA, proliferating cell nuclear antigen; Ras, rat sarcoma; Raf, RAF proto-oncogene serine/threonine protein kinase; ERK, extracellular regulated protein kinases; RNI, reactive nitrogen intermediates; ROS, reactive oxygen species; STAT, signal transducers and activators of transcription; STAT3, signal transduction and activation of transcription 3; SYD, ShaoYao Decoction; TNF, tumor necrosis factor; TNF- $\alpha$, tumor necrosis factor- $\alpha$; TGF- $\beta 1$, transforming growth factor- $\beta 1$; TNFR, tumor necrosis factor receptor; TPS, Tea polysaccharides; TRADD, TNF receptorassociated death domain; TRAIL, TNF-related apoptosis-inducing ligand; UC, ulcerative colitis; XIAP, X-linked inhibitor of apoptosis protein.
}

To date, the underlying molecular biological mechanisms of $\mathrm{CRC}$ are not fully understood, while there is a certain correlation between inflammation and cancer development, and the vital role of cytokines and various immune mediators in chronic tumorigenesis has been recognized (Qu et al., 2018). Multiple processes like tumor initiation and metastasis are involved in colitis-associated neoplasia. The pathogenesis of CAC is reported to be affected by multiple pathways, including TGF- $\beta / S M A D$, WNT/ $\beta$-catenin, NOD/TLR, NLRP3 inflammasome, and the cell cycle as well as apoptosis, etc. (Nasuno et al., 2014; Choi et al., 2017; Cao and $\mathrm{Xu}, 2019)$, among which apoptosis is most focused on since the loss of adenomatous polyposis coli (APC) and TP53 mutations are crucial in IBD-CRC formation and IBD neoplasia initiation (Rogler, 2014).

In clinical settings, several approaches are taken in the treatment of CAC. For example, COX-2 inhibitor, aminosalicylates (5-ASA), and ursodesoxycholic acid have been clinically applied to target pathways like NF- $\kappa$ B and oxidative stress (Foersch and Neurath, 2014). Meanwhile, a series of western medicines exert considerable ameliorative effect on CAC through modulating apoptotic pathways in animal experiments; the most typical are tauroursodeoxycholic acid (Kim et al., 2019), celecoxib (Setia et al., 2014), and simvastatin (Cho et al., 2008). In addition, surgery, chemotherapeutic agents, and radiotherapy are employed for CAC patients in severe stage. Apart from western medicine mentioned above, there is a class of traditional herbal medicine, also known as ethnic drugs, that display great anti-CAC potential. At present, there are few reports on the treatment of CAC by herbal medicines through inducing apoptosis-associated signaling transductions, and there is a lack of relevant systematic review. In this article, we collect the details of the ameliorative effects of ethnic drugs on CAC, aiming to provide a reference for the future clinical use of ethnic dugs in CAC treatment.

\section{APOPTOSIS IN NORMAL INTESTINAL EPITHELIA}

Defined as a highly modulated physiological process of cell death, apoptosis is activated and regulated by a class of specific genes (Kaczanowski, 2016; Ismail et al., 2019). Upon activation, cells become rounded and retract from those nearby, after which apoptotic bodies are formed through the blebbing of dynamic plasma membrane. Meanwhile, nucleus condensation and the hydrolysis of nuclear DNA into fragments can be observed (Dhuriya et al., 2019). Unlike pyroptosis, which can trigger inflammatory response, the cell membrane structure is not damaged, and no contents are released during the whole apoptosis process (Zhang et al., 2019). Functionally, apoptosis maintains homeostasis and keeps the dynamic balance of cell numbers, and, as a defense mechanism, it eliminates abnormal cells (Norbury and Hickson, 2001). In brief, apoptosis can be activated by two separate pathways, namely the intrinsic and extrinsic pathways, referring to mitochondrial and death receptor pathways, respectively (Pfeffer and Singh, 2018). 
Specifically, apoptosis affects intestinal physiology through maintaining normal colonic epithelia, the colonic crypt structure, and organ size (Keku et al., 2008; Ismail et al., 2019). In mammalian large intestine, epithelial cells are generated by the stem cells of the colonic crypts. The colonic crypt structure is affected by both apoptosis at the top of the crypt and cell proliferation at the bottom (Wang Y. et al., 2016; Kim et al., 2017; López-Posadas et al., 2017). The imbalance of apoptosis will result in the failure of colonic epithelial cell homeostasis and the cleaning-up of abnormal colonic epithelial cells, which eventually leads to colorectal cancer.

\section{DYSREGULATION OF APOPTOSIS IN CAC}

As mentioned above, multiple genes have impacts on apoptosis, and the mutation or abnormal expressions of these genes may lead to apoptosis dysfunction. CAC is elicited from inflamed mucosa and progresses in the order of "inflammation-dysplasiacarcinoma" (Axelrad et al., 2016; Romano et al., 2016; Luo and Zhang, 2017). Prior to CAC, there is usually a long period of IBD. The typical characteristics of IBD are sustained mucosal inflammation with enhanced oxidative stress, promoted epithelium proliferation, and supported angiogenesis, which contributes to the initiation and progression of cancer (Romano et al., 2016; Luo and Zhang, 2017). It is reported that numerous cells or molecules, including immune cells, chemokines, stromal cells, epithelial cells, reactive oxygen species (ROS), and reactive nitrogen intermediates (RNI) and cytokines, participate in the modulation of the IBD microenvironment (Scarpa et al., 2014; Francescone et al., 2015).

Among them, ROS and RNI released by inflammatory cells directly damage colonic epithelium and, on the other hand, promote the genetic alterations driving carcinogenesis (Axelrad et al., 2016). The signaling transductions of JNK/MAPK and $\mathrm{WNT} / \beta$-catenin are proved to be the key mechanism of colonic inflammation-tumor transformation (Kinugasa and Akagi, 2016). Besides, cytokines such as TNF- $\alpha$, IL- $1 \alpha / \beta$, or IL- 6 can trigger STAT3 signaling transduction and NF- $\kappa \mathrm{B}$ transcription, promoting tumor cell proliferation and survival as well as immune response (Klampfer, 2011; Kumari et al., 2016; Li et al., 2018). As a typical immune cell, the regulatory $\mathrm{T}$ cell is demonstrated to modulate the secretion of TNF- $\alpha$ or IL-6/11/22 so as to affect colonic cancer progression (Ju et al., 2017). On the other hand, TP53-mediated tumor cell apoptosis also exerts an important role in CAC pathogenesis. TP53 mutation is a key factor of apoptosis and is involved in IBD neoplasia initiation (Axelrad et al., 2016). Compared with p53, the dysfunction of which occurs early in CAC carcinogenesis, adenomatous polyposis coli (APC) gene mutation is elicited much later during the process of $\mathrm{CAC}$ tumorigenesis (Dyson and Rutter, 2012; Yaeger et al., 2016; Sanchez-Vega et al., 2018). It is reported that the loss of APC function will lead to insufficient $\beta$-catenin degradation, followed by the enhanced gene expression of survivin, and that survivin plays an important role in suppressing apoptosis through the inhibitory effect on caspase-3/7 and the release of cytochrome C. Moreover, some non-coding RNAs also play important roles in the apoptosis imbalance of CAC. miR-19a could promote CAC by regulating tumor necrosis factor alpha-induced protein 3-NF- $\mathrm{KB}$ feedback loops (Wang T. et al., 2016). It was found that miR-21knockdown was associated with increased expression of PDCD4 gene and inhibition of NF- $\kappa \mathrm{B}$ activation as well as down-regulation of STAT3 and bcl-2 activation (Shi et al., 2016). In addition, it was reported that targeted deletion of mir-139-5p could activate MAPK, NF- $\kappa$ B, and STAT3 signaling and decrease apoptosis and promote CAC (Zou et al., 2016). In summary, inhibition of apoptosis is a pivotal mechanism of CAC, and how to effectively promote the apoptosis of colorectal cancer cells has clinical significance for the treatment of CAC and may provide a feasible direction for the development of CAC-ameliorative drugs.

\section{MOLECULAR TARGETS OF APOPTOSIS AFFECTED BY HERBAL MEDICINES IN CAC}

Since apoptosis inhibition is a crucial factor in CAC pathogenesis, inducing apoptosis of colorectal cancer cells can be regarded as an effective way to treat CAC. Apoptotic pathways include intrinsic and extrinsic apoptotic pathways, both of which are correlated with multiple other pathways, such as TGF- $\beta / \mathrm{SMAD}, \mathrm{WNT} / \beta$-catenin, NOD/TLR, and NLRP3 inflammasome, during the molecular nosogenesis of CAC. Thus, drugs that can induce apoptosis by acting on key targets of those pathways are promising candidates for the future treatment of CAC. Herbal medicine is a treasure house of medicine with multiple components and targets, and they have been believed to exert definite curative effects in the treatment of colorectal diseases for centuries. The following will detail the studies of herbal medicines and their components, as well as formulas for the treatment of CAC through modulating both intrinsic and extrinsic apoptotic pathways.

As depicted in Figure 1, the intrinsic pathway is also referred to as the mitochondrial-dependent apoptotic pathway and is regulated by the B-cell lymphoma 2 (Bcl-2) family of proteins (Zaman et al., 2014; Wang et al., 2019). The Bcl-2 family consists of not only pro-apoptotic proteins (Bax, Bak, etc.), but also antiapoptotic proteins (Bcl-2, Bcl-Xl, etc.) (Siddiqui et al., 2015; Warren et al., 2019). In terms of mechanism, a variety of apoptotic stimuli mediate the over-expressions of BH3-only proteins, followed by the activations of both Bax and Bak in cytoplasm (Glab et al., 2017). They are then transferred to mitochondrial membrane, forming transmembrane pores and meanwhile reducing mitochondrial membrane potential (MCMP). After that, cytochrome $\mathrm{C}$ release is triggered because of the elevated permeability of mitochondrial membrane, resulting in apoptosome formation and the conversion from procaspase-9 to caspase-9 (Hassan et al., 2014; Zaman et al., 2014). This complex then activates several downstream effector caspases, such as caspase-3/6/7, and further induces DNA fragmentation and cell death (Anania et al., 2016; Tengku Din et al., 2018). Moreover, X-linked inhibitor of apoptosis protein (XIAP) and survivin, which are from the inhibitor of apoptosis 


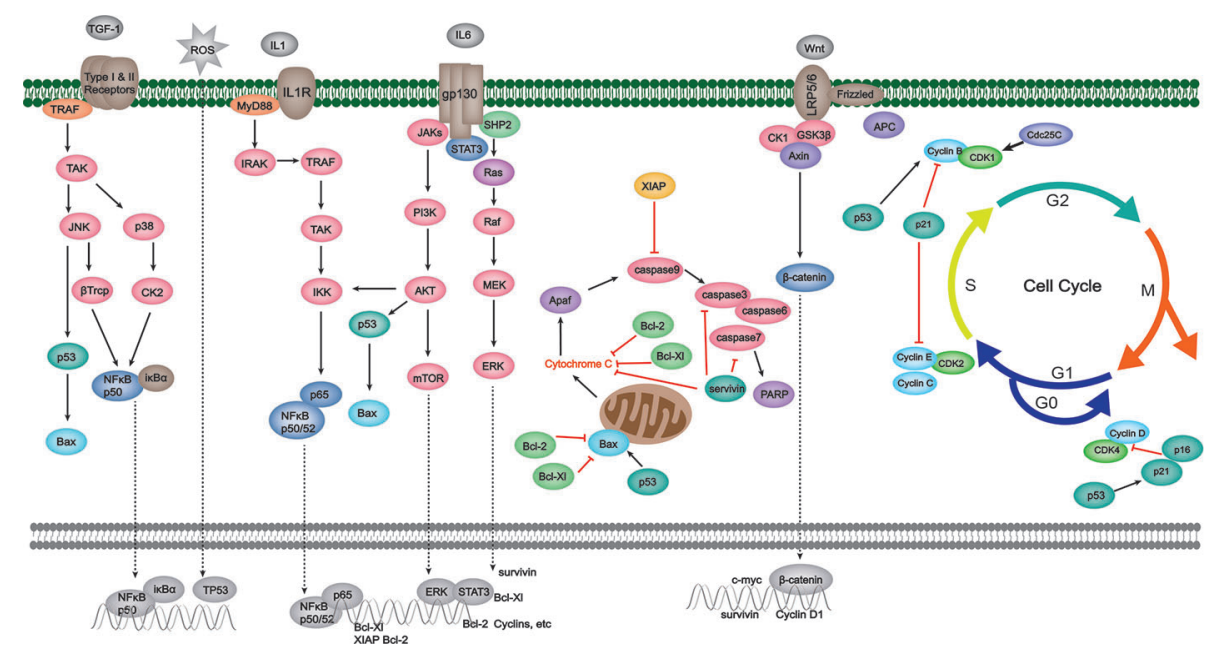

FIGURE 1 | Effects of herbal medicine on the intrinsic pathway of apoptosis.

proteins (IAP) family, can directly bind and inhibit key effector caspases such as caspase-3/7/9, thereby preventing apoptosis (Park et al., 2017).

Moreover, several other signaling pathways are also capable of regulating apoptosis through intrinsic means in the pathogenesis of CAC. Examples are as follows. (1) the activation of STAT3 induced by IL- 6 is able to up-regulate the expression of several survival proteins like $\mathrm{Bcl}-2, \mathrm{Bcl}-\mathrm{Xl}$, and survivin (Taniguchi and Karin, 2014; Siveen et al., 2014; Chonov et al., 2019). (2) NF- $\kappa$ B, MAPK, and PI3K/AKT transductions are reported to initiate $\mathrm{WNT} / \beta$-catenin signaling with or without APC, regulating apoptosis as well as neoplastic transformation(Mohammed et al., 2016), some of which also encode XIAP (Taniguchi and Karin, 2014; Romano et al., 2016; Evans et al., 2018). (3) The cyclin-dependent kinase inhibitor (CDKI) p21 is vital for p53mediated G1/S boundary cell cycle arrest and cell senescence (Kim et al., 2017) (even although additional p53 target genes are also involved in the latter process).

The extrinsic pathway is also known as the death receptormediated apoptotic pathway. Shown in Figure 2, this pathway is primarily activated by extracellular signals that are normally recognized by the proteins of the tumor necrosis factor receptor (TNFR) family (also termed death receptors), such as Fas (also known as CD95 or Apo1), TRAIL-R, and TNFR (Ntuli, 2012; Sharma et al., 2019; Ian and Chaudhry, 2019). The extracellular signals mainly contain Fas ligand (Fas-L), TNF-related apoptosis-inducing ligand (TRAIL), and tumor necrosis factor (TNF), and the gene expression of Fas can be promoted by p53 (Goldar et al., 2015; Ray et al., 2016). The binding of ligands and their specific receptors then recruits death signal adaptor proteins, such as Fas-associated death domain (FADD) and TNF receptor-associated death domain (TRADD), to the death receptors (Zaman et al., 2014; Liu et al., 2017). After that, the death-inducing signaling complex (DISC) is formed by the oligomerized receptors and recruited adaptor proteins (Qiao and Benjamin, 2009). DISC can bind to procaspase- 8 and produce active caspase- 8 , thereby promoting the activation of caspase-3/6/7 and leading to apoptotic events. In addition, the activation of caspase- 8 is also a link between extrinsic and intrinsic pathways through the activation of BID (Green and Llambi, 2015). Cellular FLICE-like inhibitory protein (c-FLIP) is an inhibitor of DISC (Zaman et al., 2014). Not only inhibiting the intrinsic pathway, XIAP also plays a role in extrinsic pathway modulation through potently inhibiting executioner caspase-3/7 (Obexer and Ausserlechner, 2014). Furthermore, NF- $\kappa$ B hyperactivation also can be observed in CAC for its contributions to the up-regulation of XIAP, c-FLIP, and p53 mutation (Grivennikov, 2013). The specific effects of herbal medicine on those signaling pathways are as follows.

\section{Monomers From Herbal Medicine}

Of monomers, polyphenols are the most widely reported treatment for CAC (shown in Figure 3). A study conducted by Kim et al. demonstrated that administration of baicalein (1-10 $\mathrm{mg} / \mathrm{kg}$ for 14 weeks) from Scutellaria baicalensis Georgi downregulated expressions of pro-caspase- $3 / 8$ so as to induce HCT-116 apoptosis through extrinsic means in a mouse model of colitis-driven colon cancer (Kim D. H. et al., 2013). Also from Scutellaria baicalensis Georgi, wogonoside (100 mg/kg/d for 15 weeks) was reported to increase the survival rate of AOM/DSSinduced CAC mice by decreasing tumor number, tumor size, average tumor load, and occurrence of large-sized adenomas through the reduction of NF- $\kappa$ B p65, p-p65, PI3K, p-Akt, cyclin $\mathrm{D} 1$, and survivin levels, as well as cytokine secretion in tumor tissue (Sun et al., 2016). Analogously, Yang et al. indicated that oroxylin A (50-200 mg/kg/d for 100 days), an active ingredient in Scutellaria baicalensis Georgi, also exerted a CAC-ameliorative property. In their study, 5-aminosalicylic acid (5-ASA) was set as a positive drug. The underlying molecular mechanism included its inhibitory effect on STAT phosphorylation as well as the 


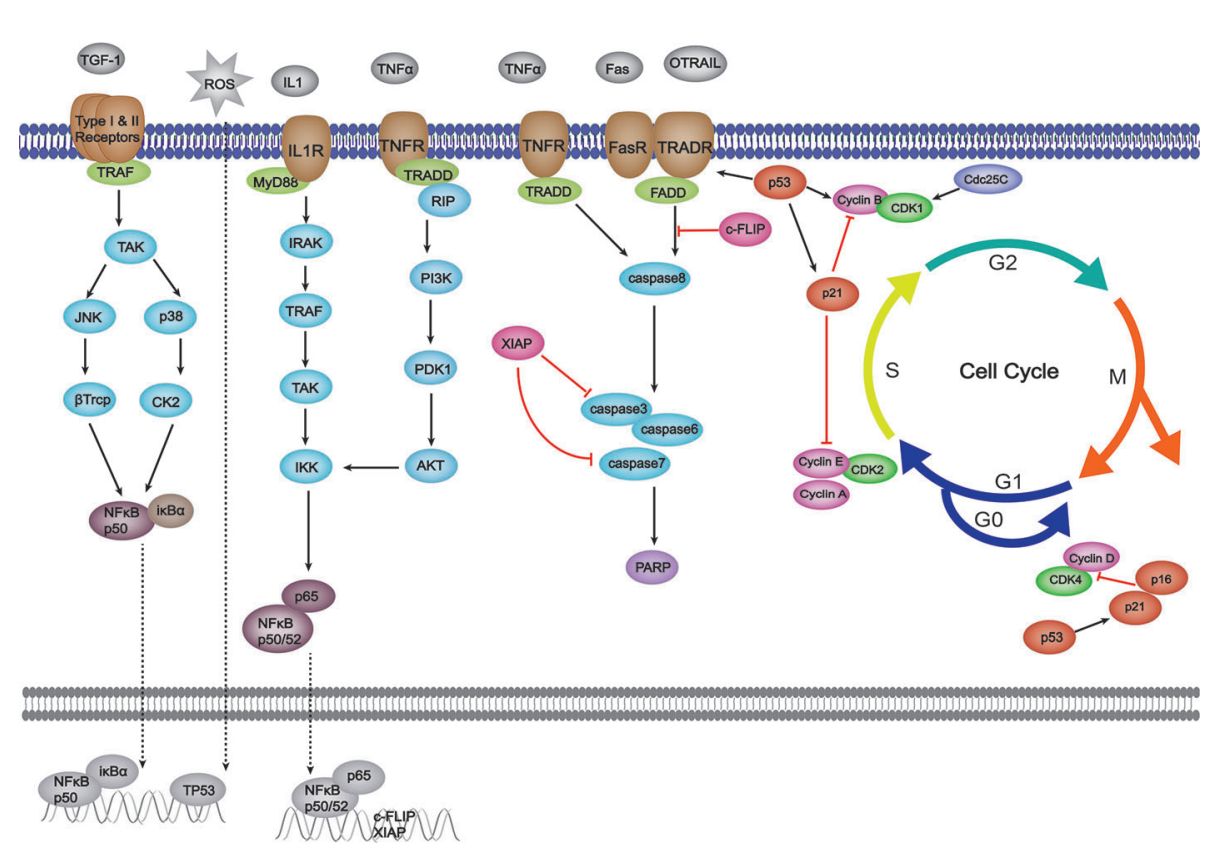

FIGURE 2 | Effects of herbal medicine on the extrinsic pathway of apoptosis.
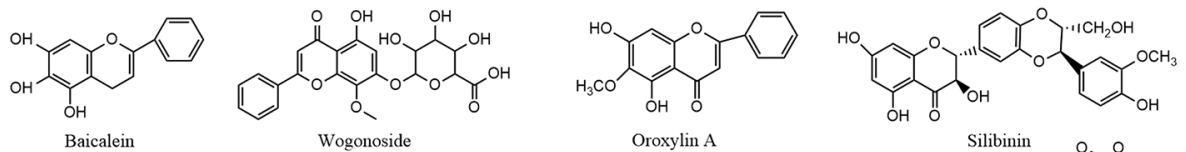<smiles>COc1ccc(-c2cc(=O)c3c(OC)c(OC)c(OC)c(OC)c3o2)cc1OC</smiles><smiles>COc1cc(/C=C/C(=O)CC(=O)/C=C/c2ccc(O)c(OC)c2)ccc1O</smiles><smiles>Oc1ccc(C=Cc2cc(O)cc(O)c2)cc1</smiles>

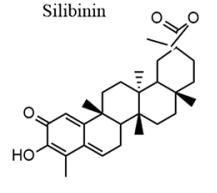

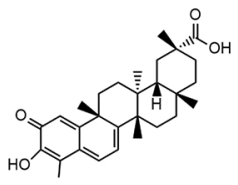

Celastrol

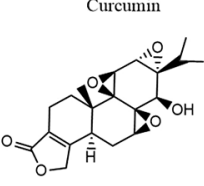<smiles>CCCCc1cc(C)cc(C)c1</smiles>

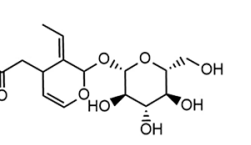<smiles>CCCCCCCCCC1C(O)CC(O)C(C)C1C</smiles>

Triptolide

Oleuropein

Embelin<smiles>C=C1C(=O)OC2C1CCC1C2(O)OC12C(C)(C)CCCC2(C)C</smiles>

FIGURE 3 | Molecular structures of reported anti-CAC compounds from herbal medicine.

expressions of Bcl-2 and cyclin D. Besides, the Bax level was elevated after oroxylin A administration, suggesting that oroxylin A induced apoptosis through modulating the IL-6/STAT3 pathway in ADM/DSS-elicited mouse colitis-associated carcinogenesis (Yang et al., 2013). Furthermore, Zheng et al. demonstrated that silibinin $(750 \mathrm{mg} / \mathrm{kg}$ for 10 weeks, dissolved in
$0.5 \%$ carboxymethyl cellulose) from Silybum marianum (L.) Gaertn also ameliorated CAC by affecting STAT3/IL6R signaling transduction (Zheng et al., 2018). Similarly, in 2017, a study reported that nobiletin from dried tangerine peel and its colonic metabolites could suppress colitis-associated colon carcinogenesis. In the study, AOM/DSS induced CRC mice 
were fed an AIN93G diet supplemented with nobiletin (0.05 wt $\%$ in diet for 20 weeks), after which the incidence and multiplicity of colonic tumors were reduced, and there were also reductions in expression of iNOS and protein levels of cyclin D, CDK6, CDK4, and CDK2 and increased levels of p27 and p53 (Wu et al., 2017). Extracted from another famous herbal medicine named Curcuma longa L., curcumin (25 mg/kg/day for 62 days) promoted the accumulation of cells in G0/G1 phase and subsequently induced tumor cell apoptosis by regulating targets that involved WNT/ $\beta$-catenin like cyclin D1 in AOM/ DSS-challenged mice (Marjaneh et al., 2018). In addition, resveratrol (0.03 wt \% in diet for 9 weeks) from white hellebore was demonstrated to reduce macroscopic lesions, dysplasia, and inflammation in colon of CAC model mice. The effect was attributed to downregulation of the levels of iNOS, COX-2, TNF- $\alpha$, and p53 (Cui et al., 2010). Moreover, isoliquiritigenin (20-500 $\mu \mathrm{g} / \mathrm{ml}$ in diet for 12 weeks) extracted from licorice could significantly reduce the incidence of tumor in colon of AOM/ DSS-induced CAC mice, which involved the decrease of iNOS, COX-2, and CD206 levels (Feng, 2017)

Terpenoids have also been repeatedly reported to be used to treat CAC. In 2018, researchers found that pristimerin (0.0001 0.0005 wt\% in diet for 10 weeks) isolated from Tripterygium wilfordii Hook $\mathrm{F}$ could inhibit cell proliferation and enhance apoptosis through regulating the cell cycle progression of colon cancer cells, because it was active in modulating targets like cyclin D1, CDC25A, p27, p21, caspase3/7/8/9, and cleaved-PARP (Park et al., 2018). Besides, Celastrol, another main constituent in Tripterygium wilfordii Hook F, is also considered as a potential candidate for CAC therapy. Also, in a mouse model of CAC established by AOM/DSS treatment, celastrol ( $2 \mathrm{mg} / \mathrm{kg} / \mathrm{d}$ for 14 weeks) was observed to significantly decrease the levels of oncogenic proteins such as p53 and $\beta$ catenin. In addition, the levels of TNF- $\alpha$, IL-1 $\beta$, IL- 6 , COX-2, and iNOS were also reduced through the inhibitory effect of celastrol on the NF- $\mathrm{K}$ B signaling pathway (Lin et al., 2015). Triptolide $(0.1,0.3,1 \mathrm{~m} \mathrm{~g} / \mathrm{kg} / \mathrm{d}$ for 20 weeks), also extracted from Tripterygium wilfordii Hook F, was reported to suppress the development of colitis and colon cancer through inducing cell apoptosis and regulating the IL-6/JAK/STAT pathway by inhibiting cyclinD1/CDK4 expression and STAT3/IL6R/JAK1 levels, respectively (Wang et al., 2009).

In addition to polyphenols and terpenoids, oleuropein (50$200 \mathrm{mg} / \mathrm{kg} / \mathrm{d}$ for 8 weeks) from Olea europaea L was confirmed to be a promising protective agent ameliorating CAC to do its ability to prevent colon inflammation, epithelial damage, and tumor formation in colon. Further investigations also utilized 5ASA as positive drug and verified that the mechanism involves oleuropein's positive effect on Bax and negative effect on p65, $\beta$ catenin, STAT3, and Akt expressions (Ginger et al., 2016). Similarity, embelin (50 mg/kg/d for 85days) from Embelia ribes Burm. F. is a well-known XIAP inhibitor and is capable of modulating p-STATS and IL-6 to decrease in the BrdUrd incorporation in dysplastic areas so that CAC progression is limited (Dai et al., 2014). In another study, parthenolide (2-4 $\mathrm{mg} / \mathrm{kg} / \mathrm{d}$ for 68 days) from Tanacetum parthenium significantly decreased the number of nodular, polypoid, and caterpillar-like tumors in the middle and distal colon of mice and meanwhile alleviated the severity of inflammation in the colons. Those effects are exerted through suppressing the expression of IкB $\alpha$ and p65, down-regulating the $\mathrm{Bcl}-2$ and $\mathrm{Bcl}-\mathrm{Xl}$ levels, and enhancing caspase-3 expression (Kim et al., 2015). Besides, crocin $(0.005,0.01,0.02 \mathrm{wt} \%$ in diet for 15 weeks) from Crocus sativus $\mathrm{L}$. was also proved to reverse the over-incidence of severe inflammation with mucosal ulcers and high-grade dysplastic crypts. The underlying mechanism is associated with its regulatory effect on NF- $\kappa \mathrm{B}, \mathrm{COX}-2$, iNOS, TNF- $\alpha$, IL- $1 \beta$, and IL-6 (Kawabata et al., 2012).

\section{Herbal Medicine Extracts}

Chung et al. conducted research to evaluate the effect of standardized ethanol extract from the aerial parts of Artemisia princeps Pampanini cv. Sajabal via (EAPP) on AOM/DSSinduced CAC, as depicted in Figure 4. The results showed EAPP (25 mg/kg/day, three times a week for 9 weeks) could inhibit the pro-inflammatory and pro-proliferative activities that
A

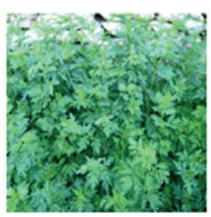

E

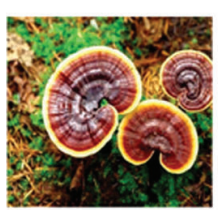

B

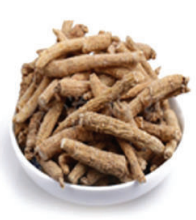

$\mathbf{F}$

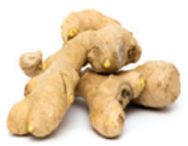

C

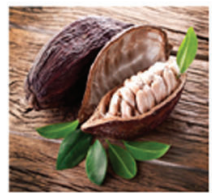

G

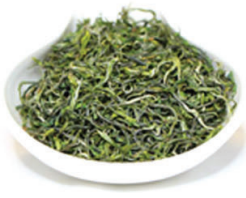

D

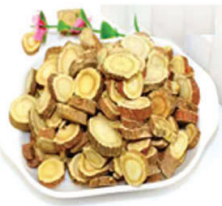

H

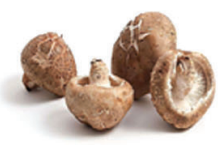

FIGURE 4 | Reported anti-CAC herbal medicines. (A) Artemisia princeps Pampanini cv, (B) American ginseng, (C) Cocoa, (D) Licorice, (E) Mushroom Ganoderma lucidum, (F) Ginger, (G) Camellia sinensis L.O. Kuntze, (H) Lentinula edodes. 
were mediated by NF- $\kappa \mathrm{B}$ and trigger apoptotic response. Briefly, EAPP decreased p65 expression and protein levels of NF- $\kappa$ Bdependent pro-survival genes, such as Bcl-2, XIAP, cFLIP, and survivin, as well as inducing caspase-3/8/9 activations (Chung et al., 2015). The hexane fraction of American ginseng $(11.9 \mathrm{mg} /$ $\mathrm{kg} / \mathrm{d}$ for 35/50 days) also suppressed CAC progression because it was capable of reducing macroscopic lesions and microscopic colon adenomas and meanwhile blocking inflammation and cancer markers. Mechanically, AG enhanced the p53 level and reversed the over-expressions of iNOS and COX-2 so as to induce apoptosis occurrence in inflammatory cells, CD4p/CD25 effector $\mathrm{T}$ cells, and lymphocytes (Poudyal et al., 2012). In addition, another study found that American ginseng could significantly downregulate the expression of cytokines (IL-1 $\alpha$, IL-1 $\beta$, IL-6, GCSF, and GM-CSF) and restore the balance of the metabolomics and intestinal flora, especially increasing the expression of Firmicutes while downregulating Bacteroidales and Verrucomicrobia (Wang C. Z. et al., 2016). In the same CAC model, cocoa (5-10\% in diet for 62 days) displayed considerable CAC-ameliorative properties by elevating the Bax and caspase- 3 levels while diminishing levels of Bcl-Xl and pro-inflammatory cytokines (TNF- $\alpha$, IL-1 $\beta$, IL-6, and IL-17), resulting in the reverse of shortening colon length and weight loss in AOM/DSSchallenged mice (Saadatdoust et al., 2015). As well as the signaling pathways mentioned above, the NF- $\kappa$ B/JAK2/STAT3 signaling pathway was focused on in another study examining whether flavonoids extracted from Licorice prevented CAC development. Licorice flavonoids $(0-100 \mathrm{mg} / \mathrm{kg}$ for 10 weeks) did affect apoptotic targets ( $\mathrm{Bax}$ and $\mathrm{Bcl}-\mathrm{Xl}$ ), proliferationassociated targets (proliferating cell nuclear antigen (PCNA), p53, p21, and cyclinD1), and inflammation-associated targets (p-JAK2, p-STAT3, IKK $\alpha / \beta$, and $p-I \kappa B \alpha)$, showing considerable potential value of clinical use against CAC (Huo et al., 2016). In another CAC mouse model established by a foodborne carcinogen (2-Amino-1-methyl-6phenylimidazol [4, 5-b] pyridine [PhIP]) plus DSS, Trierpene extract isolated from Mushroom Ganoderma lucidum (GLT) exerted significant ameliorative effect. The tumor incidence and multiplicity were suppressed after GLT administration (0-500 mg/kg for 17 weeks), and the mechanism was revealed to be correlated with the inhibition of cyclin D1 and COX-2 expression in colon tissue
(Sliva et al., 2012). Furthermore, a study showed that oral administration of ginger-derived nanoparticles (GDNPs) (0.3 $\mathrm{mg} / \mathrm{mouse} /$ day for 19 weeks) could significantly reduce the incidence and growth of CAC in AOM/DSS-induced mice. The underlying molecular mechanisms were related to the downregulation of proliferation marker cyclin D1 and proinflammatory cytokines such as IL-6, IL-1 $\beta$, and TNF- $\alpha$ (Zhang M. et al., 2016). HLiu et al. reported that tea polysaccharides (TPS) (0-200mg/kg for 13weeks) from Camellia sinensis L.O. Kuntze inhibited AOM/DSS-induced development of CAC cancer, promoted the apoptosis ratio in a mouse model, and suppressed cell proliferation in CT26 cells via arresting the cell cycle through modulating the expression of cyclin D1, MMP-2, and MMP-9 (Liu L. Q. et al., 2018). Similarly, tea polyphenols, the main components of tea, exerted good effect on the treatment of CAC in mice. It was observed that tea polyphenols $(0.1 \%$ in water for 42 days) inhibited the formation of tumor through downregulating the expression of COX-2, TNF- $\alpha$, IL- 6 , $\beta$-catenin, and $\mathrm{C}$-myc and up-regulating the expression of IL-4 and IL-10 (Mo et al., 2017). As a kind of polysaccharide exerted from Lentinula edodes, Lentinan (0-20mg/kg for 7-21 days) could also produced anti-cancer effects in an AOM/DSS-induced CAC mice model by inhibiting the TLR4/NF- $\kappa$ B signaling pathway (Perse and Cerar, 2012; Liu Y. et al., 2018).

\section{Chinese Medicinal Formulae}

Shenling Baizhu San, presented in Figure 5, is also a well-known Chinese medicine formula, which is comprised of ten commonly used herbs (as shown in Table 2) and has been used for the treatment of gastrointestinal disorders for centuries. In the study of Lin et al., SBS (7.28 g/ $\mathrm{kg}$ for 15 weeks) administration was able to significantly down-regulate the levels of neoplastic markers such as PCNA, $\beta$-catenin, and p53 as well as TGF- $\beta 1$ and $\mathrm{Wnt} 5 \mathrm{a}$ in a mouse model of CAC established by AOM/DSS treatment (Lin et al., 2015). Huangqin Decoction (HQD), composed of Scutellaria baicalensis Georgi, Paeonia lactiflora Pall, Glycyrrhiza uralensis Fisch, and Ziziphus jujuba Mill, is a famous formula from the Shang Han Lun that has been widely used in the fight against gastrointestinal symptoms (Zhang et al., 2010; Chen et al., 2015). HQD (9.1g/kg/day for 16 weeks) was observed to increase the survival rate, prevent the shortening of colon length,
A

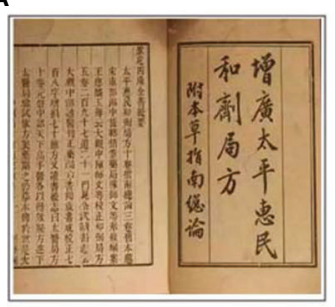

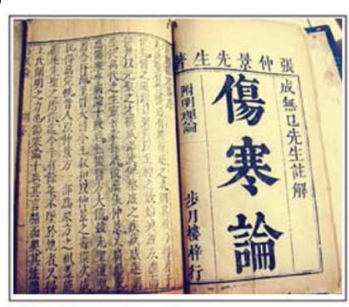

C

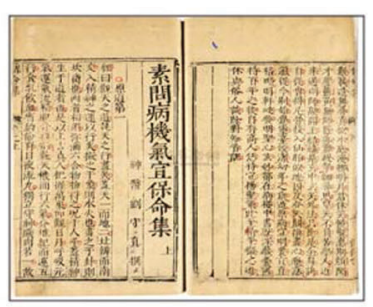

FIGURE 5 | Anti-CAC formulas documented in ancient books. (A) The prescriptions of the Bureau of Taiping People's Welfare Pharmacy describing Shenling Baizhu San. (B) 'Shang Han Lun' documenting Huangqin Decoction. (C) 'Plain Questions - anthology on proper therapy for Qi disorder and pathogenesis to save life' describing Shaoyao Decoction. 
TABLE 1 | Effects of the monomers, extracts, or formulas of herbal medicines on apoptosis-related pathway molecules.

\begin{tabular}{|c|c|c|c|c|c|c|c|c|c|}
\hline $\begin{array}{l}\text { Herbal } \\
\text { medicine }\end{array}$ & Cell & Dose & $\begin{array}{l}\text { Treatment } \\
\text { time }\end{array}$ & Animal & Dose & $\begin{array}{l}\text { Treatment } \\
\text { time }\end{array}$ & Pathway & Related targets & Reference \\
\hline Baicalein & HCT-116 & $\begin{array}{l}25,50 \\
100 \mu \mathrm{M}\end{array}$ & $24 \mathrm{~h}$ & $\begin{array}{l}\text { Male ICR mice } \\
\text { (five weeks old) }\end{array}$ & $\begin{array}{c}1,5,10 \mathrm{mg} / \\
\mathrm{kg} / \mathrm{d}\end{array}$ & $14 \mathrm{w}$ & $\begin{array}{l}\mathrm{NF}-\kappa \mathrm{B} \\
\text { extrinsic } \\
\text { pathway }\end{array}$ & $\begin{array}{l}\text { Pro-caspase-3/-8/-9, PARP, } \\
\text { plкB } \alpha, p 50, \text { p } 65, \text { iNOS, } \\
\text { MMP- } 2 \downarrow \\
\text { cleaved PARP, PPAR } \gamma \uparrow\end{array}$ & $\begin{array}{l}\text { Kim D. H. } \\
\text { et al., } 2013\end{array}$ \\
\hline Wogonoside & $\begin{array}{l}\text { HCT116, HT29, } \\
\text { THP-1 cells }\end{array}$ & $\begin{array}{c}50 \\
100 \\
150 \mu \mathrm{M}\end{array}$ & $24 \mathrm{~h}$ & $\begin{array}{l}\text { C57BL/6 mice } \\
\text { (6-8 weeks } \\
\text { old) }\end{array}$ & 100 mg/kg & $15 w$ & $\begin{array}{l}\text { P13K/AKt, } \\
\text { NF-кB } \\
\text { pathway }\end{array}$ & 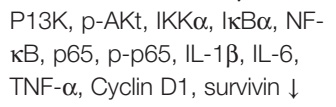 & $\begin{array}{l}\text { Sun et al., } \\
2016\end{array}$ \\
\hline Oroxylin A & HCT-116 & $\begin{array}{l}25,50 \\
100 \mu \mathrm{M}\end{array}$ & $1 \mathrm{~h}$ & $\begin{array}{l}\text { Male and } \\
\text { female } \\
\text { C57BL/6 mice } \\
\text { (6-8 weeks } \\
\text { old) }\end{array}$ & $\begin{array}{c}50,100 \\
200 \mathrm{mg} / \mathrm{kg} / \\
\mathrm{d}\end{array}$ & $100 d$ & $\begin{array}{l}\text { NF-кB, } \\
\text { IL-6/STAT3 } \\
\text { pathway }\end{array}$ & $\begin{array}{l}\text { IL-6, IL-1 } \beta \text {, } \\
\text { p-STAT3, STAT3 } \downarrow\end{array}$ & $\begin{array}{l}\text { Yang et al., } \\
2013\end{array}$ \\
\hline Silibinin & $\begin{array}{l}\text { IMCE and HCT- } \\
116\end{array}$ & $\begin{array}{c}50 \\
100 \\
200 \\
400 \\
800 \mu \mathrm{M}\end{array}$ & $72 \mathrm{~h}$ & $\begin{array}{l}\text { Female } \\
\text { C57BL/6J } \\
\text { mice (6 weeks } \\
\text { old) }\end{array}$ & $\begin{array}{c}750 \mathrm{mg} / \mathrm{kg} / \\
\mathrm{d}\end{array}$ & $10 w$ & $\begin{array}{l}\text { IL-6/STAT3 } \\
\text { pathway }\end{array}$ & IL-6, IL-1 $\beta$, TNF- $\alpha$, p-STAT3 $\downarrow$ & $\begin{array}{l}\text { Zheng et al., } \\
2018\end{array}$ \\
\hline $\begin{array}{l}\text { Nobiletin and } \\
\text { its metabolites }\end{array}$ & $\begin{array}{l}\text { RAW } 264.7 \\
\text { cells, } \\
\text { HCT116 cells }\end{array}$ & $\begin{array}{c}0.5,1 \\
2 \mu \mathrm{g} / \mathrm{ml}\end{array}$ & $24 \mathrm{~h}$ & $\begin{array}{l}\text { Male CD-1 } \\
\text { mice }\end{array}$ & $\begin{array}{l}500 \text { ppm } \\
\text { nobiletin in } \\
\text { diets }\end{array}$ & $20 w$ & $\begin{array}{l}\text { Nrf2 pathway, } \\
\text { Cell cycle } \\
\text { pathway }\end{array}$ & $\begin{array}{l}\text { iNOS, cyclinE, cyclinD, CDK6, } \\
\text { CDK4, CDK2 } \downarrow \\
\text { Nif2, HO-1, NQO1, p21, p27, } \\
\text { p53个 }\end{array}$ & $\begin{array}{l}\text { Wu et al., } \\
2017\end{array}$ \\
\hline $\begin{array}{l}\text { Phytosomal } \\
\text { curcumin }\end{array}$ & CT-26 & $\begin{array}{c}0-1000 \\
\mu \mathrm{M}\end{array}$ & $24 / 48 / 72 \mathrm{~h}$ & $\begin{array}{l}\text { Female C57/6 } \\
\text { mice (8 weeks } \\
\text { old) }\end{array}$ & $25 \mathrm{mg} / \mathrm{kg} / \mathrm{d}$ & $62 d$ & $\begin{array}{l}\text { WNT } \\
\text { / } \beta \text {-catenin } \\
\text { pathway }\end{array}$ & $\beta$-catenin,cyclin D1 $\downarrow$ & $\begin{array}{l}\text { Marjaneh } \\
\text { et al., } 2018\end{array}$ \\
\hline Resveratrol & & & & $\begin{array}{l}\text { Male and } \\
\text { female C57BL } \\
6 \text { mice (8-12 } \\
\text { weeks old) }\end{array}$ & $\begin{array}{l}300 \text { ppm } \\
\text { resveratrol in } \\
\text { diets }\end{array}$ & $9 w$ & $\begin{array}{l}\text { Oxidative } \\
\text { stress, NF-кB } \\
\text { pathway }\end{array}$ & iNOS, COX-2, TNF- $\alpha$, p53 $\downarrow$ & $\begin{array}{l}\text { Cui et al., } \\
2010\end{array}$ \\
\hline Isoliquiritigenin & & & & $\begin{array}{l}\text { Male BALB/c } \\
\text { mice ( } 6 \text { weeks } \\
\text { old) }\end{array}$ & $\begin{array}{l}20,100,500 \\
\mu \mathrm{g} / \mathrm{ml} \\
\text { isoliquiritige } \\
\text { in diets }\end{array}$ & $12 w$ & $\begin{array}{l}\text { Oxidative } \\
\text { stress }\end{array}$ & 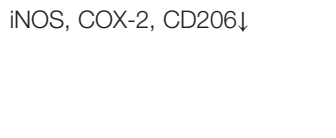 & Feng, 2017 \\
\hline Pristimerin & & & & $\begin{array}{l}\text { Female BALB/ } \\
\text { c mice ( } 5 \\
\text { weeks old) }\end{array}$ & $\begin{array}{l}\text { 1-5 ppm } \\
\text { Pristimerin } \\
\text { diets }\end{array}$ & $10 w$ & $\begin{array}{l}\text { NF-к B, } \\
\text { AKT/FOXO3a } \\
\text { pathway, } \\
\text { extrinsic/ } \\
\text { intrinsic } \\
\text { pathway, cell } \\
\text { cycle }\end{array}$ & 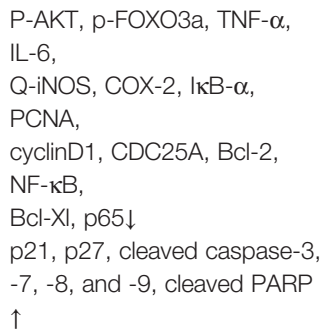 & $\begin{array}{l}\text { Park et al., } \\
2018\end{array}$ \\
\hline Celastrol & $\begin{array}{l}\text { HCT116, } \\
\text { HT-29 cells }\end{array}$ & $\begin{array}{l}0-40 \\
\mu \mathrm{M}\end{array}$ & $24,48 h$ & $\begin{array}{l}\text { Male C57BL/6 } \\
\text { mice (6-8 } \\
\text { weeks old), } \\
\text { male BALB/c- } \\
\text { nu mice (5 } \\
\text { weeks old) }\end{array}$ & $\begin{array}{l}2 \mathrm{mg} / \mathrm{kg} / \mathrm{d} \\
1,2 \mathrm{mg} / \mathrm{kg}\end{array}$ & $\begin{array}{l}14 w \\
18 d\end{array}$ & $\begin{array}{l}\text { NF-кB } \\
\text { pathway, } \\
\text { p53-related } \\
\text { pathway, } \\
\text { EMT-related } \\
\text { pathway }\end{array}$ & $\begin{array}{l}\text { NF-кBp65, TNF- } \alpha, I L-6, I L- \\
1 \beta, C O X-2, \text { iNOS, p53, p- } \\
\text { p53, N-cadherin, Vimentin, } \\
\text { Snail, } \beta \text {-catenin } \downarrow \\
\text { E-cadherin } \uparrow\end{array}$ & $\begin{array}{l}\text { Lin et al., } \\
2016\end{array}$ \\
\hline Triptolide & $\begin{array}{l}\text { SW480 cells } \\
\text { Caco } 2 \text { cells }\end{array}$ & $\begin{array}{c}10,30 \\
100 \\
300 \mathrm{nM}\end{array}$ & $24,48,72 \mathrm{~h}$ & Male ICR mice & $\begin{array}{c}0.1,0.3,1 \\
\mathrm{mg} / \mathrm{kg} / \mathrm{d}\end{array}$ & $20 w$ & $\begin{array}{l}\text { JAK/STAT3 } \\
\text { pathway, } \\
\text { Cell cycle } \\
\text { pathway }\end{array}$ & $\begin{array}{l}\text { IL-6R, IL-6, JAK1, } \\
\text { STAT3, Rac1, Cyclin D1, CDK } \\
4 \downarrow\end{array}$ & $\begin{array}{l}\text { Wang et al., } \\
2009\end{array}$ \\
\hline Crocin & & & & $\begin{array}{l}\text { Male ICR Mice } \\
\text { (4 weeks old) }\end{array}$ & $\begin{array}{l}50,100 \\
200 \text { ppm } \\
\text { crocin in } \\
\text { diets }\end{array}$ & $15 / 4 w$ & $\begin{array}{l}\mathrm{NF}-\kappa \mathrm{B} \\
\text { signaling } \\
\text { pathway }\end{array}$ & $\begin{array}{l}\text { NF- } \kappa \text { B, COX-2, } \\
\text { iNOS, TNF- } \alpha, I L-1 \beta, I L-6 \downarrow \\
\text { Nrf2 } \uparrow\end{array}$ & $\begin{array}{l}\text { Kawabata } \\
\text { et al., } 2012\end{array}$ \\
\hline Oleuropein & & & & $\begin{array}{l}\text { Female } \\
\text { C57BL/6 mice }\end{array}$ & $\begin{array}{c}50,100 \mathrm{mg} / \\
\mathrm{kg}\end{array}$ & $8 w$ & 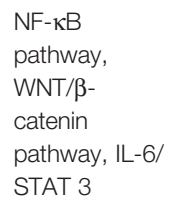 & $\begin{array}{l}\text { p65, NF- } \kappa \text { B, TNF- } \alpha, \beta- \\
\text { catenin, Cox-2, IL-6, STAT3, } \\
\text { AKt, IFN- } \gamma, \text { IL-17A } \downarrow \\
\text { Bax } \uparrow\end{array}$ & $\begin{array}{l}\text { Ginger et al., } \\
2016\end{array}$ \\
\hline
\end{tabular}

(Continued) 
TABLE 1 | Continued

\begin{tabular}{|c|c|c|c|c|c|c|c|c|c|}
\hline $\begin{array}{l}\text { Herbal } \\
\text { medicine }\end{array}$ & Cell & Dose & $\begin{array}{l}\text { Treatment } \\
\text { time }\end{array}$ & Animal & Dose & $\begin{array}{l}\text { Treatment } \\
\text { time }\end{array}$ & Pathway & Related targets & Reference \\
\hline Embelin & HCT116 & $\begin{array}{c}20 \\
\mu \mathrm{mol} / \mathrm{L}\end{array}$ & $1-24 \mathrm{~h}$ & $\begin{array}{l}\text { Male C57BL/6 } \\
\text { mice (6- } \\
\text { 8weeks) }\end{array}$ & 50 mg/kg & $85 d$ & $\begin{array}{l}\text { pathway, } \\
\text { P53-related } \\
\text { pathway, } \\
\text { P13K/AKt } \\
\text { pathway } \\
\text { IL-6/STAT3 } \\
\text { pathway }\end{array}$ & $\begin{array}{l}\text { IL-6, p-STAT3, IL-1 } \beta, \text { IL-17a, } \\
\text { IL-23 } \downarrow \\
\text { p-SHP2 } \uparrow\end{array}$ & $\begin{array}{l}\text { Dai et al., } \\
2014\end{array}$ \\
\hline Parthenolide & & & & $\begin{array}{l}\text { Female Balb/C } \\
\text { mice ( } 6 \text { weeks } \\
\text { old) }\end{array}$ & $2,4 \mathrm{mg} / \mathrm{kg}$ & $68 d$ & $\begin{array}{l}\mathrm{NF}-\kappa \mathrm{B} \\
\text { pathway }\end{array}$ & $\begin{array}{l}\text { |кB } \alpha, N F-\kappa B-p 65, \text { Bcl-2, Bcl- } \\
\text { XI } \downarrow \\
\text { Caspase-3 } \uparrow\end{array}$ & $\begin{array}{l}\text { Kim et al., } \\
2015\end{array}$ \\
\hline $\begin{array}{l}\text { Extract of } \\
\text { Artemisia } \\
\text { princeps } \\
\text { Pampanini }\end{array}$ & $\begin{array}{l}\text { HT-29 } \\
\text { HT-116 }\end{array}$ & $\begin{array}{c}60 \\
120 \\
180 \mu \mathrm{g} / \\
\mathrm{ml}\end{array}$ & $6 \mathrm{~h}$ & Male ICR mice & $\begin{array}{l}25 \mathrm{mg} / \mathrm{kg} / \mathrm{d} \\
\text { three times } \\
\text { a week }\end{array}$ & $9 w$ & $\begin{array}{l}\mathrm{NF}-\kappa \mathrm{B} \\
\text { extrinsic/ } \\
\text { intrinsic } \\
\text { pathway }\end{array}$ & $\begin{array}{l}\text { P65, survivin, cFLIP, clAP, } \\
\text { XIAP, Bcl-2, Bcl-XI, Mcl-1, } \\
\text { TNF- } \alpha, P-I L-1 \beta \downarrow \\
\text { Q-PARP-1 } 1\end{array}$ & $\begin{array}{l}\text { Chung et al., } \\
2015\end{array}$ \\
\hline \multicolumn{10}{|l|}{$\begin{array}{l}\text { cv. } \\
\text { Sajabal } \\
\text { (EAPP) }\end{array}$} \\
\hline $\begin{array}{l}\text { American } \\
\text { Ginseng } \\
\text { (Hexane } \\
\text { fraction) }\end{array}$ & $\begin{array}{l}\text { ANA-1 murine } \\
\text { macrophage, } \\
\text { TK6 } \\
\text { lymphoblastoid } \\
\text { cells, } \\
\mathrm{CD}^{+} / \mathrm{CD} 25^{-} \\
\text {effector T cells }\end{array}$ & $\begin{array}{c}260 \mu \mathrm{g} / \\
\mathrm{ml}, 0- \\
1000 \\
\mu \mathrm{g} / \mathrm{ml}, \\
0-300 \\
\mu \mathrm{g} / \mathrm{ml}\end{array}$ & $24 \mathrm{~h}$ & Mice & $\begin{array}{c}11.9 \mathrm{mg} / \mathrm{kg} / \\
\mathrm{d}\end{array}$ & $35 / 50 d$ & $\begin{array}{l}\text { Oxidative } \\
\text { stress } \\
\text { pathway }\end{array}$ & iNOS, COX-2 $\downarrow$ & $\begin{array}{l}\text { Poudyal } \\
\text { et al., } 2012\end{array}$ \\
\hline Cocoa & & & & $\begin{array}{l}\text { Female BALB/ } \\
\text { c mice }\end{array}$ & $\begin{array}{l}5 \%, 10 \% \\
\text { cocoa in } \\
\text { diets }\end{array}$ & $62 \mathrm{~d}$ & $\begin{array}{l}\text { NF- } \mathrm{KB} / \\
\text { IL-6/STAT3, } \\
\text { extrinsic } \\
\text { pathway }\end{array}$ & $\begin{array}{l}\text { Bcl-XI, IL-6, CD68 }{ }^{+}, \text {PCNA, } \\
\text { IL-17, IL-1 } \beta, \text { TNF- } \alpha, \text { NF- } \kappa B \text {, } \\
\text { p-STAT3 }{ }^{Y 705} \downarrow \\
\text { Bax, caspase- } 3 \uparrow\end{array}$ & $\begin{array}{l}\text { Saadatdoust } \\
\text { et al., } 2015\end{array}$ \\
\hline $\begin{array}{l}\text { Licorice } \\
\text { flavoids (LFS) }\end{array}$ & & & & $\begin{array}{l}\text { Female } \\
\text { C57BL/6 mice }\end{array}$ & $\begin{array}{c}50,100 \mathrm{mg} / \\
\mathrm{kg} / \mathrm{d}\end{array}$ & $10 w$ & $\begin{array}{l}\text { NF-кB/IL-6/ } \\
\text { Jak2/Stat3, } \\
\text { p53 pathway }\end{array}$ & 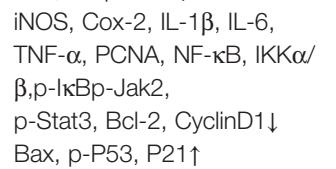 & $\begin{array}{l}\text { Huo et al., } \\
2016\end{array}$ \\
\hline $\begin{array}{l}\text { Ganoderma } \\
\text { lucidum } \\
\text { triterpene } \\
\text { extract }\end{array}$ & & & & $\begin{array}{l}\text { Male ICR mice } \\
\text { (5weeks old) }\end{array}$ & $\begin{array}{l}\text { 0, 100, } 500 \\
\mathrm{mg} / \mathrm{kg} \text { (three } \\
\text { times per } \\
\text { week) }\end{array}$ & $17 w$ & $\begin{array}{l}\mathrm{NF}-\kappa \mathrm{B} \text {, cell } \\
\text { cycle pathway }\end{array}$ & $\begin{array}{l}\text { CyclinD1, COX-2, CYP1A2, } \\
\text { CYP3A4 } \downarrow\end{array}$ & $\begin{array}{l}\text { Sliva et al., } \\
2012\end{array}$ \\
\hline $\begin{array}{l}\text { Nanoparticles } \\
\text { derived from } \\
\text { edible ginger }\end{array}$ & $\begin{array}{l}\text { RAW264.7 cells, } \\
\text { Caco-2BBE, } \\
\text { Colon-26 cells }\end{array}$ & $\begin{array}{l}0-100 \\
\mu \mathrm{g} / \mathrm{ml}\end{array}$ & $24 h$ & $\begin{array}{l}\text { Female } \\
\text { C57BL/6 or } \\
\text { FVB/NJ mice } \\
\text { (6-8 weeks } \\
\text { old) }\end{array}$ & $\begin{array}{l}0.3 \mathrm{mg} / \\
\text { mouse }\end{array}$ & $19 w$ & $\begin{array}{l}\text { Cell cycle } \\
\text { pathway }\end{array}$ & $\begin{array}{l}\text { TNF- } \alpha, \text { IL-6, IL-1 } \beta \text {, CyclinD1 } \\
\text { IL-10, IL-22 } \uparrow\end{array}$ & $\begin{array}{l}\text { Zhang M. } \\
\text { et al., } 2016\end{array}$ \\
\hline $\begin{array}{l}\text { Tea } \\
\text { polysaccharide } \\
\text { (TPS) }\end{array}$ & CT-26 cells & $\begin{array}{c}20-320 \\
\mu \mathrm{g} / \mathrm{ml}\end{array}$ & $48 h$ & BALB/c mice & $\begin{array}{l}0-200 \mathrm{mg} / \\
\mathrm{kg}\end{array}$ & $13 w$ & $\begin{array}{l}\text { Cell cycle } \\
\text { pathway }\end{array}$ & CyclinD1, MMP-2, MMP-9 $\downarrow$ & $\begin{array}{l}\text { Liu L. Q. } \\
\text { et al., } 2018\end{array}$ \\
\hline $\begin{array}{l}\text { Tea } \\
\text { polyphenols }\end{array}$ & & & & $\begin{array}{l}\text { Male BALB/c } \\
\text { mice ( } 4 \text { weeks } \\
\text { old) }\end{array}$ & $\begin{array}{c}0.1 \% \text { in } \\
\text { water }\end{array}$ & 42 days & $\begin{array}{l}\text { WNT/ } \beta- \\
\text { catenin } \\
\text { pathway }\end{array}$ & $\begin{array}{l}\text { COX-2, TNF- } \alpha, \| L-6, \beta- \\
\text { catenin, C-myc } \downarrow \\
\| \mathrm{L}-4, \mathrm{IL}-10 \uparrow\end{array}$ & $\begin{array}{l}\text { Mo et al., } \\
2017\end{array}$ \\
\hline Lentinan & RAW264.7 cells & $\begin{array}{l}0.5,1 \\
2 \mathrm{mg} / \\
\mathrm{ml}\end{array}$ & $24 h$ & $\begin{array}{l}\text { Female } \\
\text { C57BL/6 mice, } \\
\text { BALB/c mice }\end{array}$ & $\begin{array}{l}5,10,20 \\
\mathrm{mg} / \mathrm{kg}, \\
5,10,20 \\
\mathrm{mg} / \mathrm{kg} \\
20 \mathrm{mg} / \mathrm{kg}\end{array}$ & $\begin{array}{c}7 \text { or } 20 \mathrm{~d} \\
7 \mathrm{~d} \\
21 \mathrm{~d}\end{array}$ & $\begin{array}{l}\text { TLR4/NF-кB } \\
\text { pathway }\end{array}$ & $\begin{array}{l}\text { MyD88, IRAK4, TRAF6, } \\
\text { IKBKB, NF-кB-p65, NF-кB, } \\
\text { IL-13, CD30L } \downarrow\end{array}$ & $\begin{array}{l}\text { Liu Y. et al., } \\
2018\end{array}$ \\
\hline $\begin{array}{l}\text { Huangqin } \\
\text { Decoction }\end{array}$ & & & & $\begin{array}{l}\text { Male C57BL/6 } \\
\text { mice (8-week } \\
\text { old) }\end{array}$ & $9.1 \mathrm{~g} / \mathrm{kg}$ & $16 w$ & $\begin{array}{l}\text { Oxidative } \\
\text { stress } \\
\text { pathway }\end{array}$ & $\begin{array}{l}\text { TNF- } \alpha, \text { IL-1 } \beta, \| L-6, \text { CSF-1, } \\
\text { MCP-1, COX-2, MPO, } \\
\text { MDA,8-oxoguanine, } \\
\text { nitrotyrosine } \downarrow\end{array}$ & $\begin{array}{l}\text { Chen et al., } \\
2016\end{array}$ \\
\hline $\begin{array}{l}\text { ShaoYao } \\
\text { decoction } \\
\text { (SYD) }\end{array}$ & & & & $\begin{array}{l}\text { Male C57BL } \\
6 J \text { mice (6and } \\
8 \text { weeks old) }\end{array}$ & $\begin{array}{l}7.12 \mathrm{~g} / \mathrm{kg} \\
\text { twice a day }\end{array}$ & $15 w$ & $\begin{array}{l}\mathrm{NF}-\kappa \mathrm{B} \\
\text { pathway }\end{array}$ & $\begin{array}{l}\beta \text {-catenin, COX-2, p53, p65, } \\
\text { PCNA, N-cadherin, } \\
\text { fibronectin, vimentin, Snail, IL- }\end{array}$ & $\begin{array}{l}\text { Lin et al., } \\
2014\end{array}$ \\
\hline
\end{tabular}


TABLE 1 | Continued

\begin{tabular}{|c|c|c|c|c|c|c|c|c|c|}
\hline $\begin{array}{l}\text { Herbal } \\
\text { medicine }\end{array}$ & Cell & Dose & $\begin{array}{c}\text { Treatment } \\
\text { time }\end{array}$ & Animal & Dose & $\begin{array}{l}\text { Treatment } \\
\text { time }\end{array}$ & Pathway & Related targets & Reference \\
\hline $\begin{array}{l}\text { Shenling } \\
\text { Baizhu San }\end{array}$ & $\begin{array}{l}\text { SW480, } \\
\text { HCT116. Cells }\end{array}$ & $\begin{array}{c}0-16 \\
\mu \mathrm{g} / \mathrm{ml}\end{array}$ & $12 / 24 h$ & $\begin{array}{l}\text { Male C57BL/6 } \\
\mathrm{J} \text { mice }\end{array}$ & $\begin{array}{c}7.28 \mathrm{~g} / \mathrm{kg} \\
\text { (twice a day) }\end{array}$ & $15 w$ & $\begin{array}{l}\text { TGF- } \beta 1 \text {, } \\
\text { WNT/ } \beta- \\
\text { catenin } \\
\text { pathway }\end{array}$ & $\begin{array}{l}1 \beta, I L-6, \text { TNF- } \alpha \downarrow \\
\text { E-cadherin } \uparrow \\
\text { TGF- } \beta 1, \text { Wnt5a, } \beta \text {-catenin, } \\
\text { PCNA, p53, N-cadherin, } \\
\text { vimentin, Fibronectin, Snail } \downarrow \\
\text { E-cadherin, Axin, Dvl2, GSK- } \\
3 \beta \uparrow\end{array}$ & $\begin{array}{l}\text { Lin et al., } \\
2015\end{array}$ \\
\hline
\end{tabular}

TABLE 2 | Herbal medicines based on the above active components.

\begin{tabular}{|c|c|}
\hline Monomers & Medicinal plants \\
\hline Crocin & Crocus sativus L, Gardenia jasminoides Ellis. \\
\hline Embelin & $\begin{array}{l}\text { Embelia ribes Burm. F.,Oxalis acetosella L, } \\
\text { Lysimachia punctata L. }\end{array}$ \\
\hline Parthenolide & Tanacetum parthenium. \\
\hline Oleuropein & $\begin{array}{l}\text { Olea europaea L., Syringa pubescens Turcz., } \\
\text { Syringa reticulata (Blume) Hara., Syringa dilatata, } \\
\text { Syringa oblata Lindl,Osmanthus cymosus, } \\
\text { Ligustrum vulgare,Ligustrum lucidum Ait., Fraxinus } \\
\text { excelsior Linn., Fraxinus ornus Linn., } \\
\text { Osmanthus fragrans (Thunb.) Lour., Fraxinus } \\
\text { americana Linn., Chionanthus virginicus L., } \\
\text { Fraxinus angustifolia, Phillyrea angustifolia L., } \\
\text { Phillyrea latifolia L. }\end{array}$ \\
\hline Wogonoside & Scutellaria baicalensis Georgi. \\
\hline Oroxylin A & $\begin{array}{l}\text { Scutellaria baicalensis Georgi.,Stachys } \\
\text { geobombycis C. Y. Wu., Oroxylum indicum (L.) } \\
\text { Kurz, Capparis spinosa L,Eucommia ulmoides } \\
\text { Oliver. }\end{array}$ \\
\hline Baicalein & Scutellaria baicalensis Georgi. \\
\hline
\end{tabular}

\section{Silibinin Silybum marianum (L.) Gaertn.}

Nobiletin Citrus tangerina, Citrus sinensis (L.) Osbeck, Citrus aurantium L.

Curcumin Curcuma longa L., Curcuma mangga, Curcuma zedoaria (Christm.) Rosc., Costus speciosus, Curcuma xanthorrhiza, Curcuma aromatica Salisb., Curcuma phaeocaulis, Etlingera elatior, Zingiber cassumunar.

Resveratrol Veratrum grandiflorum (Maxim.) Loes. F., Cassia sp.,Polygonum Cuspidatum,Arachis hypogaea Linn., Eucalyptus robusta Smith, Vitis vinifera L., Morus alba L., Picea sp., Vaccinum sp.,c,Artocarpus sp., Rheum rhaponticum L., Reynoutria japonica Houtt., Gnetum montanum Markgr., Bauhinia purpurea L., Pinus sylvestris L., Veratrum sp.

Celastrol Tripterygium wilfordii Hook F, Tripterygium hypoglaucum (Levl.) Hutch,. Tripterygium regelii Sprague et Takeda.

Pristimerin Maytenus ilicifolia, Celastrus orbiculatus Thunb. Celastrus hypoleucus (Oliv.) Warb.ex Loes., Salacia oliveriana,Maytenus Heterophylla,Maytenus senegalensis (Lam.) Exell., Triterpygium wilfordii Hook F.

Triptolide Tripterygium wilfordii Hook F., Celastrus orbiculatus Thunb., Tripterygium hypoglaucum (Levl.) Hutch.
Reference

Pham et al., 2000

Lu H. et al.,

2016

Ghantous

et al., 2013

Hassen

et al., 2015

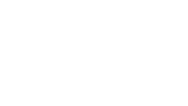

Sun et al.,

2016

Lu L. et al., 2016

\section{Kim D. H.}

et al., 2013

Zheng et al.,

2018

Li et al.,

2014

Aggarwal

et al., 2007

Huang et al., 2019

\section{Kim H. J.}

et al., 2013; Venkatesha et al., 2016 Kim H. J. et al., 2013

Zhang C. et al., 2017 and reduce the number of tumors, tumor size, and tumor load of AOM/DSS-induced CAC mice after oral gavage. Further research indicated that HQD could reduce the levels of TNF- $\alpha$, IL-1 $\beta$, IL-6, CSF-1, MCP-1, and COX-2, which suggested that HQD might improve CAC through its anti-oxidative and antiinflammation properties (Chen et al., 2016). In addition, another canonical Chinese medicine prescription named ShaoYao decoction (SYD) was reported to have a mitigating effect on CAC. SYD includes nine herbs: Radix Paeoniae Alba, Radix Angelicae Sinensis, Rhizoma Coptidis L, Semen Arecae, Radix Aucklandiae, Radix Et Rhizoma Glycyrrhizae, Radix Et Rhizoma Rhei, Radix Scutellariae, and Cortex Cinnamomi. After receiving SYD (7.12 g/kg for 15 weeks), increased survival rate and reduced incidence and multiplicity of colonic neoplasms were detected in AOM/DSS-induced CAC mice. The authors concluded that the alleviating effects of SYD on CAC were through inhibiting the expression levels of PCNA, $\beta$-catenin, COX-2, and p53 in colon tissue. Moreover, the levels of IL- $1 \beta$, IL- 6 , TNF- $\alpha$, and NF- $\kappa$ B were also down-regulated by SYD, suggesting that SYD might ameliorate CAC by suppressing NF- $\kappa$ B activation (Lin et al., 2014).

\section{HERBAL MEDICINES BASED ON THE ABOVE ACTIVE COMPONENTS}

The active components mentioned above for the treatment of CAC are also widely distributed in many medicinal plants (Figure 6). Crocin is a water-soluble carotenoid that is found in the stigma of saffron (Crocus sativus L.) and the fruit of gardenia (Gardenia jasminoides Ellis) (Pham et al., 2000). Embelin is a benzoquinone that is purified from the fruits of Embelia ribes Burm. $\mathrm{F}$ and is also found in other medicinal plants, such as Oxalis acetosella L. and Lysimachia punctata L. (Lu H. et al., 2016). Parthenolide, which is extracted from the shoots of feverfew (Tanacetum parthenium), is a kind of sesquiterpene lactone (Ghantous et al., 2013). Oleuropein is one of the most abundant active components contained in the leaves of the olive tree (Olea europaea L.), and it can be isolated from many other medicinal plants like Syringa pubescens Turcz, Ligustrum lucidum Ait, and Chionanthus virginicus L. (Hassen et al., 2015). It is of interest that most of the active constituents are either polyphenols or terpenoids. Among them, wogonoside, oroxylin A, baicalein, silibinin, nobiletin, curcumin, and 

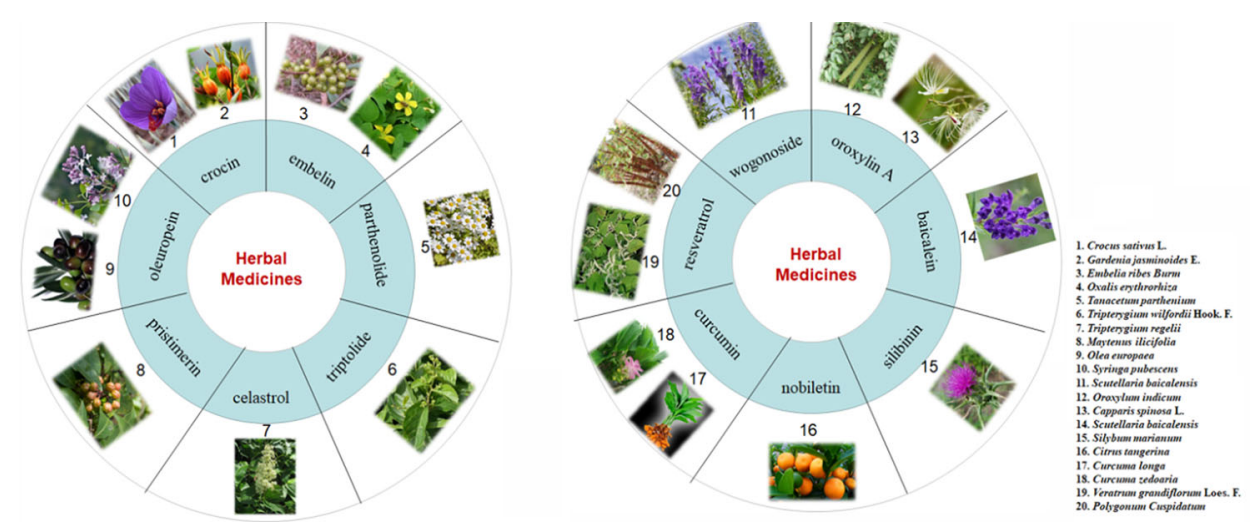

FIGURE 6 | Other sources of reported monomers with anti-CAC properties.

resveratrol are polyphenols. Of note, wogonoside, oroxylin A, and baicalein are all active constituents of Scutellaria baicalensis Georgi., a Chinese traditional medicine that has been widely used for thousands of years. It is worth mentioning that oroxylin A is also found in Oroxylum indicum (L.) Kurz. (Lu L. et al., 2016). Silibinin is mainly derived from the seeds of milk thistle (Silybum marianum (L.) Gaertn.). In addition, nobiletin is mainly present in the peels of tangerine (Citrus tangerina), sweet orange (Citrus sinensis (L.) Osbeck), and bitter orange (Citrus aurantium $\mathrm{L}$ ) (Li et al., 2014), curcumin has a two-century history and can be extracted from Curcuma longa L., Curcuma zedoaria (Christm.) Rosc., and Curcuma aromatica Salisb. (Aggarwal et al., 2007). Pure resveratrol was first isolated from the roots of white hellebore (Veratrum grandiflorum O. Loes) in 1940, and it has also been found to exist in the roots of Rheum rhaponticum $\mathrm{L}$. (Huang et al., 2019). The active ingredient in licorice, which plays an anti-CAC role, is another polyphenol (Huo et al., 2016). In addition, Artemisia princeps Pampanini cv. Sajabal and cocoa are also rich in polyphenols (Ju et al., 2012).

Apart from polyphenols, terpenoids are the second-largest group of active constituents for CAC treatment, among which the typical ones are triptolide, celastrol, and pristimerin. Celastrol is a quinone methide triterpenoid first extracted from the root bark of the Chinese medicine 'Thunder of God Vine' (also known as Tripterygium wilfordii Hook F) in 1936 (Yang et al., 2006; Hou et al., 2019). Pristimerin (a species of quinone methide triterpenoid) and triptolide (a species of diterpenoid triepoxide) are also capable of being isolated from Tripterygium wilfordii Hook F (Kim H. J. et al., 2013; Hou et al., 2019; Zhang C. et al., 2017). It is surprising that these three components are all active constituents of Tripterygium wilfordii Hook F and that they are also abundant in the Celastraceae and Hippocrateaceae families (Kim H. J. et al., 2013; Venkatesha et al., 2016). Moreover, Ganoderma triterpenoids also exert considerable ameliorative effects on CAC (Sliva et al., 2012). The details of the sources of the main ingredients are as follows.

\section{ADVERSE EFFECTS}

Overall, no serious adverse effects have been reported by the studies conducted in herbal medicine (Wu J. et al., 2019; Payab et al., 2020). There was reportedly a low risk of adverse events associated with the uses of American ginseng, Licorice, Ginger, and Lentinula edodes in maintaining well-being, decreasing nausea or vomiting in early-stage pregnant women, ameliorating postoperative sore throat, and preventing nodal metastasis in breast cancer patients, respectively (Arring et al., 2018; Stanisiere et al., 2018; Kuriyama and Maeda, 2019). However, heavy metal contents in Coca, such as nickel and aluminum, displayed potential adverse non-carcinogenic health effects in consumers (Salama, 2018). In one study, adverse effects like gastrointestinal, skin, and subcutaneous tissue disorders were observed after the consumption of Artemisia princeps Pampanini cv (Vitalone et al., 2012). As for Mushroom Ganoderma lucidum, most participants tolerate it well, and only three episodes of toxicity were recorded until 2016; two patients had nausea, and one experienced insomnia (Jin et al., 2016). Moreover, the mutagenicity and acute and subchronic toxicity of Camellia sinensis L.O. Kuntze was examined in a rat model, and the results indicated that the level of no observed adverse effects was $4.0 \mathrm{~g} / \mathrm{kg}$ bw/day (Li et al., 2011).

\section{FUTURE PROSPECTS}

Conventional therapies for CAC include tauroursodeoxycholic acid (Kim et al., 2019), celecoxib (Setia et al., 2014), and simvastatin et (Cho et al., 2008). However, the high risk of side effects seriously influences the quality of life of patients. Furthermore, long-term use may lead to drug resistance and reduce efficacy. In recent years, more and more attention has been paid to the applications of herbal medicine to CAC treatment. Compared to synthetic drugs, herbal medicine 
exerts characteristics of multiple-targeting and correlatively low adverse effects. Over the past decades, numerous studies have been conducted to make advances in anti-CAC investigations of herbal medicine. On the basis of CAC pathogenesis, this work aimed to evaluate the efficacy, underlying mechanisms, and safety of reported herbal medicine in CAC treatment. To date, more than 20 kinds of herbal medicine are confirmed to have CAC-ameliorative properties, and the underlying mechanisms through apoptosis modulation are shown in Figures 1, 2 and Table 1. We found that apoptosis imbalance in CAC is closely related to anti-cancer gene mutations (TP53, APC, etc.) that are caused by oxidative stress occurrence and the abnormal signaling transductions of multiple pathways (such as MAPK, NF- $\kappa \mathrm{B}$, and JAK/STAT) as well as the elevated expressions of anti-apoptotic proteins (such as Bcl-2/Xl, XIAP, and c-FLIP). At present, herbal medicines have been proved to be effective in preventing CAC progression by affecting apoptosis in both intrinsic and extrinsic ways, as well as regulating the MAPK, NF- $\kappa \mathrm{B}$, and JAK/STAT pathways. Apparently, the majority of research efforts have mainly concentrated on the mechanisms involved in colonic inflammatory response and colon cancer apoptosis and metastasis, while modulation on the cell cycle arrest, Ras/Raf/ERK, and WNT/ $\beta$ catenin pathways, respectively accounting for tumor cell proliferation, invasion, and premalignant lesion, have not been thoroughly studied. In addition, one study, through mitochondrial proteomics, identified an important differential protein named sixtransmembrane epithelial antigen of prostate 4 (STEAP4), which was highly expressed and promoted mitochondrial iron accumulation and oxidative stress, thus promoting the occurrence of CAC. The study further found that the hypoxia/HIF-2 alpha/ STEAP4/mitochondrial iron/mitochondrial ROS axis promoted colitis and colon cancer development (Xue et al., 2017). As yet, there have been no studies on the improvement of CAC by herbal medicine through modulating STEAP4 or related signaling pathways. Further studies are needed. On the other hand, the dose-effect relationship is a criterion for judging how well a drug works, and toxicity is supposed to be taken into consideration first when evaluating efficacy. We notice that, the dose range of monomer, extracts, and formula is $0-1000 \mu \mathrm{M} / 1-750 \mathrm{mg} / \mathrm{kg}$ (cell/animal), $0-2 \mathrm{mg} / \mathrm{mL} / 0-500 \mathrm{mg} / \mathrm{mL}$ (cell/animal), and 0-16 $\mu \mathrm{g} / \mathrm{mL} / 7.12-9.1 \mathrm{~g} / \mathrm{kg}$ (cell/animal), respectively. Generally, herbal medicines exert low toxicity and have no serious side effects even with a long period of use; the typical side effects are slight skin or gastrointestinal disorders like skin rash and nausea. This suggests that herbal medicines have a relatively wide range of safety (Payab et al., 2020).

Emerging evidence has shown that the efficacy of herbal medicine can be improved by promoting bioavailability by chemical structure modification and dosage form transformation. It is of note that herbal medicines, especially their monomer contents, have low oral bioavailability, in some cases no more than $1 \%$ (Wu J. S. et al., 2019). To date, some new, natural, and lowtoxicity drug delivery systems have been developed in experimental studies, such as ginger-derived nanoparticles, that could target the inflamed bowel mucosa and show a promising direction for the prevention and treatment of IBD and CAC (Zhang M. et al., 2016).
In terms of ingredient categories, the active constituents of reported anti-CAC herbal medicines mainly include polyphenols, terpenoids, and saccharide. We therefore collected information on other herbal medicines that have the ingredients mentioned above as their main constituents (displayed in Table 2), even though there is no evidence indicating their CAC-ameliorative activation so far. For example, Zanthoxylum bungeanum Max (ZBM), also known as Szechuan pepper, has been used in the fight against gastrointestinal disorders for centuries. It is cultivated over a wide geographical range and has substantial production, much higher than that of other medicinal herbs (Li et al., 2016). The essential oil and pericarp of ZBM have been demonstrated to have a positive impact on experimental colitis via the regulation of the NF- $\kappa$ B/PPAR- $\gamma$ and TLR4-related signaling pathways, respectively (Zhang Z. et al., 2016; Zhang Z. et al., 2017), suggesting its great potential to be a CAC-ameliorative candidate. Similarly, the traditional Chinese medicine 'Qing Dai (Indigo naturalis)' also showed therapeutic effects on ulcerative colitis and could be a promising anti-CAC drug (Suzuki et al., 2013). Furthermore, it is worth mentioning that the active constituents responsible for the anti-CAC properties of herbal medicines like ginger, American ginseng, and Shaoyao decoction have not been clearly identified and still need further investigation.

Last but not least, the existing studies on the herbal medicineCAC relationship remain at the experimental level; data from clinical trials are limited. The effectiveness and the relevant underlying molecular mechanism through which herbal medicines play a role as anti-CAC drugs are still unclear. Our results confirm the effectiveness of herbal medicine such as Artemisia princeps Pampanini cv, American ginseng, and Licorice in the treatment for CAC through apoptosis modulation. However, there is still a desperate need to determine better anti-CAC drug candidates with more potent effects and lower levels of side effects. Furthermore, the pathogenesis of CAC has not been fully elucidated, and the apoptosis-related pathways regulated by herbal medicine are not fully explored. It will be meaningful to continue to track progress on the impact of herbal medicine on CAC.

To sum up, herbal medicines are promising drugs with multiple regulatory targets, especially in apoptosis-related pathways, while more knowledge is still needed before they meet clinical requirements and can be further applied to the prevention and therapy of CAC. In addition, more efforts are needed to promote the bioavailability of herbal medicines as well as their monomer contents so as to reach a balance between therapeutic efficacy and toxicological safety.

\section{AUTHOR CONTRIBUTIONS}

RT and XL wrote the draft. YL searched the literature. JW and FY drew the figures. SJ prepared the tables. HL checked literature and data. CZ and JW supervised the work. 


\section{FUNDING}

This work was supported by the National Key Research and Development Program of China [2017YFC1703904], the National Natural Science Foundation of China [81773974, 81774284 and

\section{REFERENCES}

Aggarwal, B. B., Sundaram, C., Malani, N., and Ichikawa, H. (2007). Curcumin: the Indian solid gold. Adv. Exp. Med. Biol. 595, 1-75. doi: 10.1007/978-0-38746401-5_1

Al Bakir, I., Curtius, K., and Graham, T. A. (2018). From colitis to cancer: an evolutionary trajectory that merges maths and biology. Front. Immunol. 9, 2368. doi: 10.3389/fimmu.2018.02368

Anania, V. G., Yu, K. B., Gnad, F., Pferdehirt, R. R., Li, H., Ma, T. P., et al. (2016). Uncovering a dual regulatory role for caspases during endoplasmic reticulum stress-induced cell death. Mol. Cell Proteomics 15, 2293-2307. doi: 10.1074/ mcp.M115.055376

Arring, N. M., Millstine, D., Marks, L. A., and Nail, L. M. (2018). Ginseng as a Treatment for Fatigue: A Systematic Review. J. Altern. Complement. Med. 24, 624-633. doi: 10.1089/acm.2017.0361

Axelrad, J. E., Lichtiger, S., and Yajnik, V. (2016). Inflammatory bowel disease and cancer: the role of inflammation, immunosuppression, and cancer treatment. World J. Gastroenterol. 22, 4794-4801. doi: 10.3748/wjg.v22.i20.4794

Cao, X., and Xu, J. (2019). Insights into inflammasome and its research advances in cancer. Tumori. 2019, 0300891619868007. doi: 10.1177/0300891619868007

Chen, P., Zhou, X., Zhang, L., Shan, M., Bao, B., Cao, Y., et al. (2015). Antiinflammatory effects of Huangqin tang extract in mice on ulcerative colitis. J. Ethnopharmacol. 162, 207-214. doi: 10.1016/j.jep.2014.12.039

Chen, G., Yang, Y., Hu, C., Cheng, X., Xu, Y., Cai, X., et al. (2016). Protective effects of Huangqin Decoction against ulcerative colitis and associated cancer in mice. Oncotarget 7, 61643-61655. doi: 10.18632/oncotarget.11426

Cho, S. J., Kim, J. S., Kim, J. M., Lee, J. Y., Jung, H. C., and Song, I. S. (2008). Simvastatin induces apoptosis in human colon cancer cells and in tumor xenografts, and attenuates colitis-associated colon cancer in mice. Int. J. Cancer 123, 951-957. doi: 10.1002/ijc.23593

Choi, C. R., Bakir, I. A., Hart, A. L., and Graham, T. A. (2017). Clonal evolution of colorectal cancer in IBD. Nat. Rev. Gastroenterol. Hepatol. 14, 218-229. doi: 10.1038/nrgastro.2017.1

Chonov, D. C., Ignatova, M. M. K., Ananiev, J. R., and Gulubova, M. V. (2019). IL6 activities in the tumour microenvironment. part 1. Open Access Maced J. Med. Sci. 7, 2391-2398. doi: 10.3889/oamjms.2019.589

Chung, K. S., Choi, H. E., Shin, J. S., Cho, E. J., Cho, Y. W., Choi, J. H., et al. (2015). Chemopreventive effects of standardized ethanol extract from theaerial parts of Artemisia princeps Pampanini cv. Sajabal via NF- $\mathrm{\kappa B}$ inactivation on colitisassociated colon tumorigenesis in mice. Food Chem. Toxicol. 75, 14-23. doi: 10.1016/j.fct.2014.11.007

Cui, ,. X., Jin, Y., Hofseth, A. B., Pena, E., Habiger, J., Chumanevich, A., et al. (2010). Resveratrol suppresses colitis and colon cancer associated with colitis. Cancer Prev. Res. (Phila) 3, 549-559. doi: 10.1158/1940-6207.CAPR-09-0117

Dai, Y., Jiao, H., Teng, G., Wang, W., Zhang, R., Wang, Y., et al. (2014). Embelin reduces colitis-associated tumorigenesis through limiting IL-6/STAT3 signaling. Mol. Cancer Ther. 13, 1206-1216. doi: 10.1158/1535-7163.MCT-13-0378

Dhuriya, Y. K., Sharma, D., and Naik, A. A. (2019). Cellular demolition: proteins as molecular players of programmed cell death. Int. J. Biol. MacromoL. 138, 492-503. doi: 10.1016/j.ijbiomac.2019.07.113

Dyson, J. K., and Rutter, M. D. (2012). Colorectal cancer in inflammatory bowel disease: what is the real magnitude of the risk? World J. Gastroenterol. 18, 3839-3848. doi: 10.3748/wjg.v18.i29.3839

Evans, M. K., Brown, M. C., Geradts, J., Bao, X., Robinson, T. J., Jolly, M. K., et al. (2018). XIAP regulation by MNK links MAPK and NFKB signaling to determine an aggressive breast cancer phenotype. Cancer Res. 78, 17261738. doi: 10.1158/0008-5472.CAN-17-1667

Feng, Y. X. (2017). Preventive effect and mechanism of diference doses of isorcyrrhizin on the induction of inflammation related colon cancer in mice
81803994], and the International Cooperation Project of Sichuan Science and Technology Department [2019YFH0152]. Science and Technology Developmental Foundation of Chengdu University of TCM [No.XSGG2019019]. induced by azoxymethane and dextran sodium sulfate. J. Gastroenterol. Hepatol. 26 (08), 873-878. doi: 10.3969/j.issn.1006-5709.2017.08.009

Foersch, S., and Neurath, M. F. (2014). Colitis-associated neoplasia: molecular basis and clinical translation. Cell. Mol. Life. Sci. 71, 3523-3535. doi: 10.1007/ s00018-014-1636-x

Francescone, R., Hou, V., and Grivennikov, S. I. (2015). Cytokines, IBD, and colitis-associated cancer. Inflammation Bowel Dis. 21, 409-418. doi: 10.1097/ MIB. 0000000000000236

Ghantous, A., Sinjab, A., Herceg, Z., and Darwiche, N. (2013). Parthenolide: from plant shoots to cancer roots. Drug Discovery Today 18, 894-905. doi: 10.1016/ j.drudis.2013.05.005

Ginger, E., Recio, M. C., Ríos, ,. J. L., Cerdá-Nicolás, ,. J. M., and Ginger, R. M. (2016). Chemopreventive effect of oleuropein in colitis-associated colorectal cancer in c57bl/6 mice. Mol. Nutr. Food Res. 60, 242-255. doi: 10.1002/mnfr.201500605

Glab, J. A., Mboqo, G. W., and Puthalakath, H. (2017). BH3-only proteins in health and disease. Int. Rev. Cell Mol. Biol. 328, 163-196. doi: 10.1016/ bs.ircmb.2016.08.005

Glover, M., Mansoor, E., Panhwar, M., Parasa, S., and Cooper, G. S. (2019). Epidemiology of colorectal cancer in average risk adults 20-39 years of age: A population-based national study. Dig. Dis. Sci. 64, 3602-3609. doi: 10.1007/ s10620-019-05690-8

Goldar, S., Khaniani, M. S., Derakhshan, S. M., and Baradarn, B. (2015). Molecular mechanisms of apoptosis and roles in cancer development and treatment. Asian Pac. J. Cancer Prev. 16, 2129-2144. doi: 10.7314/apjcp.2015.16.6.2129

Green, D. R., and Llambi, F. (2015). Cell death signaling. Cold Spring Harb. Perspect. Biol. 7, a006080. doi: 10.1101/cshperspect.a006080

Grivennikov, S. I. (2013). Inflammation and colorectal cancer: colitis-associated neoplasia. Semin. Immunopathol. 35 (2), 229-244. doi: 10.1007/s00281-0120352-6

Hassan, M., Watari, H., AbuAlmaaty, A., Ohba, Y., and Sakuragi, N. (2014). Apoptosis and molecular targeting therapy in cancer. BioMed. Res. Int. 2014, 150845. doi: $10.1155 / 2014 / 150845$

Hassen, I., Casabianca, H., and Hosni, K. (2015). Biological activities of the natural antioxidant oleuropein: Exceeding the expectation-A mini-review. J. Funct. Foods 18, 926-940. doi: 10.1016/j.jff.2014.09.001

Hnatyszyn, A., Hryhorowicz, S., Kaczmarek-Ryś, M., Lis, E., Słomski, R., Scott, R. J., et al. (2019). Colorectal carcinoma in the course of inflammatory bowel diseases. Hered. Cancer Clin. Pract. 17, 18. doi: 10.1186/s13053-019-0118-4

Hou, W., Liu, B., and Xu, H. (2019). Triptolide: Medicinal chemistry, chemical biology and clinical progress. Eur. J. Med. Chem. 176, 378-392. doi: 10.1016/ j.ejmech.2019.05.032

Huang, X. T., Li, X., Xie, M. L., Huang, Z., Huang, Y. X., Wu, G. X., et al. (2019). Resveratrol: review on its discovery, anti-leukemia effects and pharmacokinetics. Chem. Biol. Interact. 306, 29-38. doi: 10.1016/j.cbi.2019.04.001

Huo, X., Liu, D., Gao, L., and Li, L. (2016). Flavonoids extracted from Licorice prevents colitis-associated carcinogenesis in AOM/DSS mouse model. J. Int. J. Mol. Sci. 17, 1343-1356. doi: 10.3390/ijms17091343

Ian, R., and Chaudhry, G. E. (2019). Understanding apoptosis and apoptotic pathways targeted cancer therapeutics. Adv. Pharm. Bull. 9, 205-218. doi: $10.15171 / \mathrm{apb} .2019 .024$

Ismail, N. I., Othman, I., Abas, F., Lajis, N. H., and Naidu, R. (2019). Mechanism of poptosis Induced by curcumin in colorectal cancer. Int. J. Mol. Sci. 20, 2454. doi: $10.3390 /$ ijms 20102454

Jin, X., Ruiz Beguerie, J., Sze, D. M., and Chan, G. C. (2016). Ganoderma lucidum (Reishi mushroom) for cancer treatment. Cochrane Database Syst. Rev. 4, CD007731. doi: 10.1002/14651858.CD007731.pub3

Ju, H. K., Lee, H. W., Chung, K. S., Choi, J. H., Cho, J. G., Baek, N. I., et al. (2012). Standardized flavonoid-rich fraction of Artemisia princeps Pampanini cv. Sajabal induces apoptosis via mitochondrial pathway in human cervical 
cancer HeLa cells. J. Ethnopharmacol. 141, 460-468. doi: 10.1016/ j.jep.2012.03.011

Ju, J., Kim, Y.-J., Park, E. S., and Park, K. (2017). Korean solar salt ameliorates colon carcinogenesis in an AOM/DSS-Induced C57BL/6 Mouse Model. Prev. Nutr. Food Sci. 22 (2), 149-155. doi: 10.3746/pnf.2017.22.2.149

Kaczanowski, S. (2016). Apoptosis: Its origin, history, maintenance and the medical implications for cancer and aging. Phys. Biol. 13, 031001. doi: 10.1088/1478-3975/13/3/031001

Kawabata, K., Tung, H. N., Shayama, Y., Sugie, S., Mori, T., and Tanaka, T. (2012). Dietary crocin inhibits colitis and colitis-associated colorectal carcinogenesis in male ICR mice. Evid. Based Complement. Altern. Med. 2012, 820415. doi: $10.1155 / 2012 / 820415$

Keku, T. O., Amin, A., Galanko, J., Martin, C., Schliebe, B., and Sandler, R. S. (2008). Apoptosis in normal rectal mucosa, baseline adenoma characteristics, and risk of future adenomas. Cancer Epidemiol. Biomarkers Prev. 17, 306-310. doi: $10.1158 / 1055-9965$

Keum, N., and Giovannucci, E. (2019). Global burden of colorectal cancer: emerging trends, risk factors and prevention strategies. Nat. Rev. Gastroenterol. Hepatol. 16, 713-732. doi: 10.1038/s41575-019-0189-8

Kim, M. H., and Kim, H. (2017). The roles of glutamine in the intestine and its implication in intestinal diseases. Int. J. Mol. Sci. 18, E1051. doi: 10.3390/ ijms18051051

Kim, D. H., Hossain, M. A., Kang, Y. J., Jang, J. Y., Lee, Y. J., Im, E., et al. (2013). Baicalein, an active component of Scutellaria baicalensis Georgi, induces apoptosis in human colon cancer cells and prevents AOM/DSS-induced colon cancer in mice. Int. J. Oncol. 43, 1652-1658. doi: 10.3892/ijo.2013.2086

Kim, H. J., Park, G. M., and Kim, J. K. (2013). Anti-inflammatory effect of pristimerin on lipopolysaccharide-induced inflammatory responses in murine macrophages. Arch. Pharm. Res. 36, 495-500. doi: 10.1007/2Fs12272-013-0054-1

Kim, S. L., Liu, Y. C., Seo, S. Y., Kim, S. H., Kim, I. H., Lee, S. O., et al. (2015). Parthenolide induces apoptosis in colitis-associated colon cancer, inhibiting NF-א B signaling. Oncol. Lett. 9, 2135-2142. doi: 10.3892/ol.2015.3017

Kim, Y. Y., Jee, H. J., Um, J. H., Kim, Y. M., Bae, S. S., and Yun, J. (2017). Cooperation between p21 and Akt is required for p53-dependent cellular senescence. Aging Cell. 16, 1094-1103. doi: 10.1111/acel.12639

Kim, Y. H., Kim, J. H., Kim, B. G., Lee, K. L., Kim, J. W., and Koh, S. J. (2019). Tauroursodeoxycholic acid attenuates colitis-associated colon cancer by inhibiting nuclear factor kappaB signaling. J. Gastroenterol. Hepatol. 34, 544-551. doi: 10.1111/jgh.14526

Kinugasa, T., and Akagi, Y. (2016). Status of colitis-associated cancer in ulcerative colitis. World J. Gastrointest. Oncol. 8 (4), 351-357. doi: 10.4251/wjgo.v8.i4.351

Klampfer, L. (2011). Cytokines, inflamation and colon cancer. Curr. Cancer Drug Targets 11, 451-464. doi: 10.2174/156800911795538066

Kumari, N., Dwarakanath, B. S., Das, A., and Bhatt, A. N. (2016). Role of interleukin-6 in cancer progression and therapeutic resistance. Tumour Biol. 37, 11553-11572. doi: 10.1007/s13277-016-5098-7

Kuriyama, A., and Maeda, H. (2019). Topical application of licorice for prevention of postoperative sore throat in adults: A systematic review and meta-analysis. J. Clin. Anesth. 54, 25-32. doi: 10.1016/j.jclinane.2018.10.025

López-Posadas, R., Neurath, M. F., and Atreya, I. (2017). Molecular pathways driving disease-specific alterations of intestinal epithelial cells. Cell Mol. Life Sci. 74, 803-826. doi: 10.1007/s00018-016-2363-2

Li, B., Jin, Y., Xu, Y., Wu, Y., Xu, J., and Tu, Y. (2011). Safety evaluation of tea (Camellia sinensis (L.) O. Kuntze) flower extract: assessment of mutagenicity, and acute and subchronic toxicity in rats. J. Ethnopharmacol. 133, 583-590. doi: 10.1016/j.jep.2010.02.030

Li, S. M., Wang, H., Guo, L. M., Zhao, H., and Ho, C. T. (2014). Chemistry and bioactivity of nobiletin and its metabolites. J. Funct. Foods 6, 2-10. doi: 10.1016/j.jff.2013.12.011

Li, P., Wu, Z., Liu, T., and Wang, Y. (2016). Biodiversity, Phylogeny, and Antifungal Functions of Endophytic Fungi Associated with Zanthoxylum bungeanum. Int. J. Mol. Sci. 17, pii: E1541. doi: 10.3390/ijms17091541

Li, Y. F., Zhu, G. Q., Zhai, H. H., Jia, ,. J. M., Yang, W. H., and Li, X. Q. (2018). Simultaneous stimulation with tumor necrosis factor- $\alpha$ and transforming growth factor- $\beta 1$ induces epithelial-mesenchymal transition in colon cancer cells via the NF-KB pathway. Oncol. Lett. 15, 6873-6880. doi: 10.3892/ ol.2018.8230
Lin, X., Yi, Z., Diao, J., Shao, M., Zhao, L., Cai, H., et al. (2014). ShaoYao decoction ameliorates colitis-associated colorectal cancer by downregulating proinflammatory cytokines and promoting epithelial-mesenchymal transition. J. Transl. Med. 12, 105. doi: 10.1186/1479-5876-12-105

Lin, X., Xu, W., Shao, M., Fan, Q., Wen, G., Li, C., et al. (2015). Shenling Baizhu San supresses colitis associated colorectal cancer through inhibition of epithelial-mesenchymal transition and myeloid-derived suppressor infiltration. BMC Complement. Altern. Med. 15, 126. doi: 10.1186/s12906015-0649-9

Lin, L., Sun, Y., Wang, D., Zheng, S., Zhang, J., and Zheng, C. (2016). Celastrol ameliorates ulcerative colitis-related colorectal cancer in mice via suppressing inflammatory responses and epithelial-mesenchymal transition. Front. Pharmacol. 6, 320. doi: 10.3389/fphar.2015.00320

Liu, H., Su, D., Zhang, J., Ge, S., Li, Y., Wang, F., et al. (2017). Improvement of pharmacokinetic profile of TRAIL via trimer-tage enhances its antitumor activity in vivo. Sci. Rep. 7, 8953. doi: 10.1038/s41598-017-09518-1

Liu, L. Q., Li, H. S., Nie, S. P., Shen, M. Y., Hu, J. L., Xie, M. Y., et al. (2018). Tea polysaccharide prevents colitis-associated carcinogenesis in mice by inhibiting the proliferation and invasion of tumor cells. Int. J. Mol. Sci. 19, 506. doi: 10.3390/ijms19020506

Liu, Y., Zhao, J., Zhao, Y., Zong, S., Tian, Y., Chen, S., et al. (2018). Therapeutic effects of lentinan on inflammatory bowel disease and colitis-associated cancer. J. Cell Mol. Med. 23, 750-760. doi: 10.1111/jcmm.13897

Lu, H., Wang, J., Wang, Y. X., Qiao, L., and Zhou, Y. M. (2016). Embelin and its role in chronic diseases. Adv. Exp. Med. Biol. 928, 397-418. doi: 10.1007/978-3319-41334-1_3

Lu, L., Guo, Q. L., and Zhao, L. (2016). Overview of oroxylin A: a promising flavonoid compound. Phytother. Res. 30, 1765-1774. doi: 10.1002/ptr.5694

Luo, C., and Zhang, H. (2017). The role of proinflammatory pathways in the pathogenesis of colitis-associated colorectal cancer. Mediators Inflamm. 2017, 5126048. doi: 10.1155/2017/5126048

Marjaneh, R. M., Rahmani, F., Hassanian, S. M., Rezaei, N., Hashemzehi, M., Bahrami, A., et al. (2018). Phytosomal curcumin inhibits tumor growth in colitis-associated colorectal cancer. J. Cell Physiol. 233, 6785-6798. doi: $10.1002 /$ jcp. 26538

Mo, L. B., Tang, Z. S., Qiao, X. Y., and Yang, Y. K. (2017). The Effect of Tea Polyphenols on Azoxymethane/dextran Sodium Sulfate Induced Colorectal Cancer in High Fat Diet Mice. Sci. Technol. Eng. 17 (26), 189-195. doi: CNKI: SUN:KXJS.0.2017-26-031

Mohammed, M. K., Shao, C., Wang, J., Wei, Q., Wang, X., Collier, Z., et al. (2016). $\mathrm{Wnt} / \beta$-catenin signaling plays an ever-expanding role in stem cell self-renewal, tumorigenesis and cancer chemoresistance. Genes Dis. 3, 11-40. doi: 10.1016/ j.gendis.2015.12.004

Nasuno, M., Arimura, Y., Nagaishi, K., Isshiki, H., Onodera, K., Nakagaki, S., et al. (2014). Mesenchymal stem cells cancel azoxymethane-induced tumor initiation. Stem. Cells 32, 913-925. doi: 10.1002/stem.1594

Norbury, C. J., and Hickson, I. D. (2001). Cellular responses to DNA damage. Annu. Rev. Pharmacol. Toxicol. 41, 367-401. doi: 10.1146/annurev.pharmtox.41.1.367

Ntuli, T. M. (2012). Apoptosis and Medicine (Novi Sad, Croatia: InTech Prepress), 71-87.

Obexer, P., and Ausserlechner, M. J. (2014). X-linked inhibitor of apoptosis protein-a critical death resistance regulator and therapeutic target for personalized cancer therapy. Front. Oncol. 4, 197. doi: 10.3389/ fonc.2014.00197

Park, C., Hong, S. H., and Choi, Y. H. (2017). Induction of apoptosis by DaeHwang-Mok-Dan-Tang in HCT-116 colon cancer cells through activation of caspases and inactivation of the phosphatidylinositol 3-kinase/Akt signaling. Integr. Med. Res. 6, 179-189. doi: 10.1016/j.imr.2017.03.003

Park, J. H., and Kim, J. K. (2018). Pristimerin, a naturally occurring triterpenoid, attenuates tumorigenesis in experimental colitis-associated colon cancer. Phytomedicine 42, 164-171. doi: 10.1016/j.phymed.2018.03.033

Payab, M., Hasani-Ranjbar, S., Shahbal, N., Qorbani, M., Aletaha, A., HaghiAminjan, H., et al. (2020). Effect of the herbal medicines in obesity and metabolic syndrome: A systematic review and meta-analysis of clinical trials. Phytother. Res. 34 (3), 526-545. doi: 10.1002/ptr.6547

Perse, M., and Cerar, A. (2012). Dextran sodium sulphate colitis mouse model: traps and tricks. J. BioMed. Biotechnol. 2012, 718617. doi: 10.1155/2012/718617 
Pfeffer, C. M., and Singh, A. T. K. (2018). Apoptosis: a target for anticancer therapy. Int. J. Mol. Sci. 19, 448. doi: 10.3390/ijms19020448

Pham, T. Q., Cormier, F., Farnworth, E., Tong, V. H., and Van Calsteren, M. R. (2000). Antioxidant properties of crocin from Gardenia jasminoides Ellis and study of the reactions of crocin with linoleic acid and crocin with oxygen. $J$. Agric. Food Chem. 48 (5), 1455-1461. doi: 10.1021/jf991263j

Poudyal, D., Le, P. M., Davis, T., Hofseth, A. B., Chumanevich, A., Chumanevich, A. A., et al. (2012). A hexane fraction of American Ginseng suppresses mouse colitis and associated colon cancer: anti-inflammatory and proapoptotic mechanisms. Cancer Prev. Res. 5, 685-696. doi: 10.1158/1940-6207.CAPR-11-0421

Qiao, L., and Wong, B. C. Y. (2009). Role of Notch signaling in colorectal cancer. Carcinogenesis 30 (12), 1979-1986. doi: 10.1093/carcin/bgp236

Qu, X., Tang, Y., and Hua, S. (2018). Immunological approaches towards cancer and inflammation: a cross talk. Front. Immunol. 9, 563. doi: 10.3389/ fimmu.2018.00563

Ray, P., Guha, D., Chakraborty, J., Banerjee, S., Adhikary, A., Chakraborty, S., et al. (2016). Crocetin exploits p53-induced death domain (PIDD) and FASassociated death domain (FADD) proteins to induce apoptosis in colorectal cancer. Sci. Rep. 6, 32979. doi: 10.1038/srep32979

Rogler, G. (2014). Chronic ulcerative colitis and colorectal cancer. Cancer. Lett. 345, 235-241. doi: 10.1016/j.canlet.2013.07.032

Romano, M., De Francesco, F., Zarantonello, L., Ruffolo, C., Ferraro, G. A., and Zanus, G. (2016). From inflammation to cancer in inflammatory bowel disease: molecular perspectives. Anticancer Res. 36, 1447-1460.

Saadatdoust, Z., Pandurangan, A. K., Sadagopan, S. K. A., Esa, N. M., Ismail, A., Mustafa, M. R., et al. (2015). Dietary cocoa inhibits colitis associated cancer: A crucial involvement of the IL-6/STAT3 pathway. J. Nutr. Biochem. 26, 15471558. doi: 10.1016/j.jnutbio.2015.07.024

Salama, A. K. (2018). Health risk assessment of heavy metalscontent in cocoa and chocolate products sold in Saudi Arabia. Toxin Rev. 38, 318-327. doi: 10.1080/ 15569543.2018.1471090

Sanchez-Vega, F., Mina, M., Armenia, J., Chatila, W. K., Luna, A., La, K. C., et al. (2018). Oncogenic signaling pathways in the cancer genome atlas. Cell. 173, 321-337. doi: 10.1016/j.cell.2018.03.035

Scarpa, M., Castagliuolo, I., Castoro, C., Pozza, A., Scarpa, M., Kotsafti, A., et al. (2014). Inflammatory colonic carcinogenesis: a review on pathogenesis and immunosurveillance mechanisms in ulcerative colitis. World J. Gastroenterol. 20, 6774-6785. doi: 10.3748/wig.v20.i22.6774

Serebriiskii, I. G., Connelly, C., Frampton, G., Newberg, J., Cooke, M., and Miller, V. (2019). Comprehensive characterization of RAS mutations in colon and rectal cancers in old and young patients. Nat. Commun. 10, 3722. doi: 10.1038/ s41467-019-11530-0

Setia, S., Nehru, B., and Sanyal, S. N. (2014). Celecoxib prevents colitis associated colon carcinogenesis: an upregulation of apoptosis. Pharmacol. Rep. 66, 10831091. doi: 10.1016/j.pharep.2014.07.001

Sharma, S., Carmona, A., Skowronek, A., Yu, F., Collins, M. O., Naik, S., et al. (2019). Apoptotic signalling targets the post-endocytic sorting machinery of the death receptor Fas/CD95. Nat. Commun. 10, 3105. doi: 10.1038/s41467019-11025-y

Shi, C., Yang, Y., Xia, Y., Okugawa, Y., Yang, J., Liang, Y., et al. (2016). Novel evidence for an oncogenic role of microRNA-21 in colitis-associated colorectal cancer. Gut 65, 1470-1481. doi: 10.1136/gutjnl-2014-308455

Siddiqui, W. A., Ahad, A., and Ahsan, H. (2015). The mystery of BCL2 family: Bcl2 proteins and apoptosis: an update. Arch. Toxicol. 89, 289-317. doi: 10.1007/ s00204-014-1448-7

Siveen, K. S., Sikka, S., Surana, R., Dai, X., Zhang, J., Kumar, A. P., et al. (2014). Targeting the STAT3 signaling pathway in cancer: role of synthetic and natural inhibitors. Biochim. Biophys. Acta 1845, 136-154. doi: 10.1016/ j.bbcan.2013.12.005

Sliva, D., Loganathan, J., Jiang, J. H., Jedinak, A., Lamb, J. G., Terry, C., et al. (2012). Mushuroom Ganoderma lucidum prevents colitis-associated carcinogenesis in mice. PloS One 7, e47873. doi: 10.1371/journal.pone.0047873

Stanisiere, J., Mousset, P. Y., and Lafay, S. (2018). How Safe Is Ginger Rhizome for Decreasing Nausea and Vomiting in Women during Early Pregnancy? Foods. 7, pii: E50. doi: 10.3390/foods7040050

Sun, Y., Zhao, Y., Wang, X., Zhao, L., LI, W., Ding, Y., et al. (2016). Wogonoside prevents colitis-associated colorectal carcinoge-nesis and colon cancer progression in inflammation-related microenvironment via inhibiting NF- $\mathrm{KB}$ activation through PI3K/Akt pathway. Oncotarget. 7, 34300-34315. doi: $10.18632 /$ oncotarget. 8815

Suzuki, H., Kaneko, T., Mizokami, Y., Narasaka, T., Endo, S., Matsui, H., et al (2013). Therapeutic impact of the herbal medicine Qing Dai (Indigo naturalis) in intractable ulcerative colitis patients. World J. Gastro. 17, 2718-2722. doi: 10.3748/wig.v19.i17.2718

Taniguchi, K., and Karin, M. (2014). IL-6 and related cytokines as the critical lynchpins between inflammation and cancer. Semin. Immunol. 26, 54-74. doi: 10.1016/j.smim.2014.01.001

Tengku Din, T. A. D. A. A., Abdul Jalal, M. I., Seeni, A., Shamsuddin, S., and Jaafar, H. (2018). The differential roles of caspase family members in mediating PF4-induced breast cancerapoptosis. Malays. J. Pathol. 40, 303-312.

Venkatesha, S. H., Dudics, S., Astry, B., and Moudgil, K. D. (2016). Control of autoimmune inflammation by celastrol, a natural triterpenoid. Pathog. Dis. 74, ftw059. doi: 10.1093/femspd/ftw059

Vitalone, A., Menniti-Ippolito, F., Raschetti, R., Renda, F., Tartaglia, L., and Mazzanti, G. (2012). Surveillance of suspected adverse reactions to herbal products used as laxatives. Eur. J. Clin. Pharmacol. 68, 231-238. doi: 10.1007/ s00228-011-1128-y

Wang, Z. P., Jin, H. F., Xu, R. D., Mei, Q. B., and Fan, D. M. (2009). Triptolide downregulates Racl and the JAK/STAT3 pathway and inhibits colitis-related colon cancer progression. Exp. Mol. Med. 41, 717-727. doi: 10.3858/ emm.2009.41.10.078

Wang, C. Z., Yu, C. H., Wen, X. D., Chen, L., Zhang, C. F., Calway, T., et al. (2016). American Ginseng Attenuates Colitis-Associated Colon Carcinogenesis in Mice: Impact on Gut Microbiota and Metabolomics. Cancer Prev. Res. (Phila) 9, 803-811. doi: 10.1158/1940-6207.CAPR-15-0372

Wang, T., Xu, X., Xu, Q., Ren, J., Shen, S., Fan, C., et al. (2016). miR-19a Promotes Colitis-Associated Colorectal Cancer by Regulating Tumor Necrosis Factor Alpha-Induced Protein 3-NF-אB Feedback Loops. Oncogene ,36, 3240-3251. doi: 10.1038/onc.2016.468

Wang, Y., George, ,. S. P., Roy, S., Pham, E., Esmaeilniakooshkghazi, A., and Khurana, S. (2016). Both the anti- and pro-apoptotic functions of villin regulate cell turnover and intestinal homeostasis. Sci. Rep. 6, 35491. doi: 10.1038/srep35491

Wang, X. B., Hou, Y., Li, Q. Y., Li, X. H., Wang, W. X., Ai, X. P., et al. (2019). Rhodiola crenulata attenuates apoptosis and mitochondrial energy metabolism disorder in rats with hypobaric hypoxia-induced brain injury by regulating the HIF- $1 \alpha /$ microRNA $210 /$ ISCU $1 / 2$ (COX10) signaling pathway. $J$. Ethnopharmacol. 241, 111801. doi: 10.1016/j.jep.2019.03.028

Warren, C. F. A., Wong-Brown, M. W., and Bowden, N. A. (2019). BCL-2 family isoforms in apoptosis and cancer. Cell Death Dis. 10, 177. doi: 10.1038/s41419019-1407-6

Wu, X., Song, M. Y., Gao, Z. L., Sun, Y., Wang, M. Q., Li, F., et al. (2017). Nobiletin and its colonic metabolites suppress colitis-associated colon carcinogenesis by down-regulating iNOS, inducing antioxidative enzymes and arresting cell cycle progression. J. Nutr. Biochem. 42, 17-25. doi: 10.1016/j.jnutbio.2016.12.020

Wu, J., Luo, Y., Jiang, Q., Li, S., Huang, W., Xiang, L., et al. (2019). Coptisine from Coptis chinensis blocks NLRP3 inflammasome activation by inhibiting caspase-1. Pharmacol. Res. 147, 104348. doi: 10.1016/j.phrs.2019.104348

Wu, J. S., Luo, Y., Deng, D., Su, S. Y., Li, S., Xiang, L., et al. (2019). Coptisine from Coptis chinensis exerts diverse beneficial properties: A concise review. J. Cell Mol. Med. 23 (12), 7946-7960. doi: 10.1111/jcmm.14725

Xue, X., Bredell, B. X., Anderson, E. R., Martin, A., Mays, C., Nagao-Kitamoto, H., et al. (2017). Quantitative Proteomics Identifies STEAP4 as a Critical Regulator of Mitochondrial Dysfunction Linking Inflammation and Colon Cancer. Proc. Natl. Acad. Sci. 114, E9608-E9617. doi: 10.1073/pnas.1712946114

Yaeger, R., Shah, M. A., Miller, V. A., Kelsen, J. R., Wang, K., Heins, Z. J., et al. (2016). Genomic alterations observed in colitis-associated cancers are distinct from those found in sporadic colorectal cancers and vary by type of inflammatory bowel disease. Gastroenterology. 151, 278-287.e6. doi: 10.1053/ j.gastro.2016.04.001

Yang, H., Chen, D., Cui, Q. C., Yuan, X., and Dou, Q. P. (2006). Celastrol, a triterpene extracted from the Chinese "Thunder of God Vine," is a potent proteasome inhibitor and suppresses human prostate cancer growth in nude mice. Cancer Res. 66, 4758-4765. doi: 10.1158/0008-5472.CAN-05-4529

Yang, X., Zhang, F. Y., Wang, Y. J., Cai, M., Wang, Q., Guo, Q. L., et al. (2013). Oroxylin A inhibits colitis-associated carcinogenesisi througn modulating the 
IL-6/STAT3 signaling pathway. Inflammation Bowel Dis. 19, 1990-2000. doi: 10.1097/MIB.0b013e318293c5e0

Zaman, S., Wang, R., and Gandhi, V. (2014). Targeting the apoptosis pathway in hematologic malignancies. Leuk. Lymphoma. 55, 1980-1992. doi: 10.3109/ 10428194.2013.855307

Zhang, W., Saif, M. W., Dutschman, G. E., Li, X., Lam, W., Bussom, S., et al. (2010). Identification of chemicals and their metabolites from PHY906, a Chinese medicine formulation, in the plasma of a patient treated with irinotecan and PHY906 using liquid chromatography/ tandem mass spectrometry (LC/MS/MS). J. Chromatogr. A. 1217, 5785-5793. doi: 10.1016/ j.chroma.2010.07.045

Zhang, M., Viennois, E., Prasad, M., Zhang, Y. C., Wang, L. X., Zhang, Z., et al. (2016). Edible ginger-derived nanoparticles: a novel therapeutic approach for the prevention and treatment of inflammatory bowel disease and colitisassociated cancer. Biomaterials. 101, 321-340. doi: 10.1016/ j.biomaterials.2016.06.018

Zhang, Z., Liu, J., Shen, P., Cao, Y., Lu, X., Gao, X., et al. (2016). Zanthoxylum bungeanum pericarp extract prevents dextran sulfate sodium-induced experimental colitis in mice via the regulation of TLR4 and TLR4-related signaling pathways. Int. Immunopharmacol. 41, 127-135. doi: 10.1016/ j.intimp.2016.10.021

Zhang, C., He, X. J., Li, L., Lu, C., and Lu, A. P. (2017). Effect of the natural product triptolide on pancreatic cancer: a systematic review of preclinical studies. Front. Pharmacol. 8, 490. doi: 10.3389/fphar.2017.00490

Zhang, Z., Shen, P., Liu, J., Gu, C., Lu, X., Li, Y., et al. (2017). In vivo study of the efficacy of the essential oil of zanthoxylum bungeanum pericarp in dextran sulfate sodium-induced murine experimental colitis. J. Agric. Food Chem. 65, 3311-3319. doi: 10.1021/acs.jafc.7b01323
Zhang, Q., Liu, J., Zhang, M., Wei, S., Li, R., Gao, Y., et al. (2019). Apoptosis induction of fibroblast-like synoviocytes is an important molecular-mechanism for herbal medicine along with its active components in treating rheumatoid arthritis. Biomolecules. 9, 795. doi: 10.3390/biom9120795

Zheng, R., Ma, J., Wang, D., Dong, W., Wang, S., Liu, T., et al. (2018). Chemopreventive effects of Silibinin on colitis-associated tumorigenesis by inhibiting IL-6/STAT3 signaling pathway. Mediators Inflamm. 2018, 1562010. doi: $10.1155 / 2018 / 1562010$

Zhu, L., Han, J., Li, L., Wang, Y., Li, Y., and Zhang, S. (2019). Claudin Family Participates in the Pathogenesis of Inflammatory Bowel Diseases and ColitisAssociated Colorectal Cancer. Front. Immunol. 10, 1441. doi: 10.3389/ fimmu.2019.01441

Zou, F. Y., Mao, R. R., Yang, L. Y., Lin, S. C., Lei, K. C., Zheng, Y. H., et al. (2016). Targeted deletion of miR-139-5p activates MAPK, NF- $\mathrm{KB}$ and STAT3 signaling and promotes intestinal inflammation and colorectal cancer. FEBS J. 283, 1438-1452. doi: 10.1111/febs.13678

Conflict of Interest: The authors declare that the research was conducted in the absence of any commercial or financial relationships that could be construed as a potential conflict of interest.

Copyright (c) 2020 Tian, Liu, Luo, Jiang, Liu, You, Zheng and Wu. This is an openaccess article distributed under the terms of the Creative Commons Attribution License (CC BY). The use, distribution or reproduction in other forums is permitted, provided the original author(s) and the copyright owner(s) are credited and that the original publication in this journal is cited, in accordance with accepted academic practice. No use, distribution or reproduction is permitted which does not comply with these terms. 